VULNERABILITY AND THE INTERNATIONAL LAW COMMISSION'S DRAFT ARTICLES ON THE PROTECTION OF PERSONS IN THE EVENT OF DISASTERS

\title{
Thérèse O'Donnell*
}

\begin{abstract}
This article ponders the possibilities existing for legal re-understandings of vulnerability and adopts the International Law Commission's Draft Articles on the Protection of Persons in the Event of Disasters (2016) as its principal discursive context. Despite some promise and potential, the draft Articles retreated to conservative understandings of disaster-vulnerability and missed an opportunity for a sophisticated formulation. This article argues for disaster law's engagement with contemporary social science research. The work of critical geographers, historians and anthropologists in political ecology is particularly apposite. By rejecting geophysical outlooks in favour of structuralist understandings of disaster vulnerability, such research facilitates consideration of inter-related histories and the role of economics in producing disaster-vulnerability. This article argues that such perspectives allow for reconsideration of current legal understandings regarding disaster-vulnerability (particularly in relation to international cooperation and risk and reduction) and thereby offer some promise for enriching disaster law's comprehensiveness and relevance.
\end{abstract}

Key words: Vulnerability - Disasters - International Law Commission - Political Ecology - Interdisciplinarity

\footnotetext{
* Reader in Law, University of Strathclyde, therese.odonnell@strath.ac.uk. Many thanks to Professor Dino Kritsiotis of the University of Nottingham and Professors Neil Hutton, Aileen McHarg, and Kenneth Norrie and Dr. Saskia Vermeylen of the University of Strathclyde. All responsibility for errors and omissions resides with the author.
} 
...words matter! ... Silences also matter. Definitions depend on models and frameworks implicit or assumed, or, often, explicit. Whatever their form, the framing of an issue (such as disaster risk reduction) nudges people to ask certain questions and not to think of others. Ben Wisner, 'UNISDR needs a better definition of 'Vulnerability'

\section{INTRODUCTION}

Vulnerability and its contexts are the central preoccupations of this article. As with any broad term like 'dignity', 'decency' ${ }^{3}$ or 'duty', ${ }^{4}$ conceptualisations of 'vulnerability' and their application have undergone multiple deployments and transformations..$^{5}$ Invocations of vulnerability in the disaster discourse must therefore be handled carefully. ${ }^{6}$ Used adjectivally in English, 'vulnerable' refers to a subject or situation that finds its own defence difficult. It suggests exposure and a susceptibility to being wounded, harmed, open to attack, exploited, criticised or tempted. Such disadvantage carries overtones of weakness, dependency, infirmity and burden. Indeed, during the Cold War, the parlance and very idea of vulnerability permeated debates regarding the risks of nuclear proliferation and disarmament. ${ }^{7}$ Just as with phrases such as 'extreme poverty', ${ }^{8}$ the tendency to adjectivise harm, particularly in the field of law and security, finds expression in terms like 'particularly vulnerable', 9 'intensifying precarity', ${ }^{10}$ 'escalating tension', 'heightened threat', 'multiplying hazards', 'increasing menace', 'proliferating risks', 'widening exposure', 'extreme peril', and 'real and present danger'. As well as illustrating the cumulative, snowballing nature of risk-exposure, the use of this phraseology also highlights vulnerability's kinetic and deluging potential. Vulnerability is rarely a static state.

1 Global Network of Civil Society Organisations for Disaster Reduction, 2018, http://www.gndr.org/programmes/advocacy/365-disasters/more-than-365-disasters-blogs/item/1519-unisdrneeds-a-better-definition-of-vulnerability.html..

${ }^{2}$ E.Webster, Dignity, Degrading Treatment and Torture in Human Rights Law (Routledge 2018), S.Leher, Dignity and human rights: language philosophy and social realizations, (Routledge 2018), P. Capps, Human Dignity and the Foundations of International Law, (Hart 2009), M. Bal, R. Debes (ed.) Dignity: a history (OUP 2017), Dignity in the Workplace New Theoretical Perspectives, (Springer 2017). For overlaps see A. Masferrer, E. GarcíaSánchez (eds.) Human Dignity of the Vulnerable in the Age of Rights: Interdisciplinary Perspectives (Springer 2016).

${ }^{3}$ T. O'Donnell 'Between the Devil and the Deep Blue Sea? A reflection on the legal dilemmas presented by the Communications Decency Act 1996 and Reno v ACLU \& Others' 1998 Anglo-Am.L.Rev. 27, 397. C. Eastaugh Unconstitutional solitude: solitary confinement and the US Constitution's evolving standards of decency (Palgrave MacMillan 2017), R. Ofreneo Asia and the Pacific: advancing decent work amidst deepening inequalities (ITUCAsia Pacific 2013).

${ }^{4}$ T. O’Donnell \& C. Allan 'A duty of solidarity?: The International Law Commission's draft articles and the right to offer assistance in disasters' in Research Handbook on Disasters and International Law. S. Breau \& K. Samuel, (eds.) (Elgar 2016) 453, M. Steup, Knowledge, truth, and duty essays on epistemic justification, responsibility, and virtue, ( OUP 2000), J. Bascom, Ethics or science of duty, (Putnam's Sons 1879).

${ }^{5}$ C. Gibb 'A critical analysis of vulnerability’ (2018) 28 International Journal of Disaster Risk Reduction 327.

${ }^{6}$ See also Susan Marks' caution regarding 'root causes' discourse, S Marks 'Human Rights and Root Causes'

(2011) 74(1) MLR 57, 77-78.

${ }^{7}$ R. Woolsey 'The Politics of Vulnerability: 1980-83' Foreign Affairs 805.

8 Tackling Inequality Vital to Ending Extreme Poverty by 2030, http://www.worldbank.org/en/news/pressrelease/2016/10/02/tackling-inequality-vital-to-end-extreme-poverty-by-2030.

9 S. Sivakumaran 'Armed Conflict-Related Detention of Particularly Vulnerable Persons: Challenges and Possibilities’ (2018) 94 International Law Studies 39.

${ }^{10}$ See for example F. Bühlmann 'Trajectories of Vulnerability: A Sequence-Analytical Approach' in: R.Tillmann, M. Voorpostel, P. Farago (eds) Social Dynamics in Swiss Society. Life Course Research and Social Policies, Vol 9 (Springer 2018). 
In contrast to 'vulnerable', the noun 'solidarity' describes a community of responsibilities and interests, and there is a regular lexical and conceptual relationship between the two terms. The current UN Secretary-General upon his nomination by the UN Security Council in October 2016, pledged to show 'the humility that is needed to serve especially those that are most vulnerable,' in particular victims of conflict, terrorism, human rights violations and poverty. ${ }^{11}$ Thus, in its challenges to full self-actualisation, its strong implications of passivity and its inhibition of the dominant Liberal ideal of autonomy, ${ }^{12}$ vulnerability is traditionally viewed as a negative state and one which, by engaging notions of affinity, concerns the international community.

This article analyses law's potential to address vulnerability in the disaster context. It argues that in reality vulnerability is conceptually complex, encompassing vulnerable States, vulnerable communities within States and vulnerable individuals within communities. However, it is equally clear that vulnerability is politically constructed and contestable. The article particularly focuses on the recently completed International Law Commission Draft Articles on the Protection of Persons in the Event of Disasters (2016). ${ }^{13}$ These draft Articles arose from concerns in the UN General Assembly about the plight of disaster-stricken communities $^{14}$ and, as draft Article 3 makes clear, the ILC Draft Articles focus on a

...calamitous event or series of events resulting in widespread loss of life, great human suffering and distress, mass displacement, or large-scale material or environmental damage, thereby seriously disrupting the functioning of society....

The ILC's task was to codify and streamline the notorious disorganisation prevailing in the field of disaster regulation, ${ }^{15}$ which was considered a key factor hampering the work of aid actors leading to inefficient delivery of international assistance. The draft Articles that were ultimately produced built on the existing dominant legal frameworks of international humanitarian law, human rights law and environmental law and large amounts of soft law. The UN General Assembly ${ }^{16}$ has taken note of the draft Articles and has invited Governments to submit comments concerning the ILC's recommendation for the creation of a convention. While the project's Special Rapporteur Eduardo Valencia Ospina favoured the conclusion of a treaty, a willingness of states to participate in such a formalistic venture is unclear. At the moment, despite much of the material codifying customary international law, the current standing of the draft Articles, as a collective instrument, is as a set of non-binding guidelines. The ILC hoped that this (potentially interim) status would allow for prompt and wide adoption by relevant actors. ${ }^{17}$

The ILC was not simply engaged in the mechanics of disaster law. As well as directing that States should remove obstacles to the expeditious and targeted delivery of assistance (such

\footnotetext{
${ }^{11}$ S. Sengupta and R. Minder 'António Guterres Pledges to Help Vulnerable as Secretary General' New York Times, 6 October 2016.

${ }^{12}$ A. Cortina \& J. Conill, 'Ethics of Vulnerability’ in Masferrer \& García-Sánchez, (n 2) 45.

${ }^{13}$ UN. Doc. A/71/10, Yearbook of the International Law Commission, 2016, vol. II, Part Two, para 48.

${ }^{14}$ Report of the International Law Commission on the work of its Fifty-Eighth Session Official Records of the General Assembly, Sixty-first Session, Supplement No. 10, UN.Doc. A/61/10, para 257.

${ }^{15}$ Int'l Law Comm'n, Sixty-third Session, UN Doc. A/66/10, para 285, at 253.

${ }^{16}$ UNGA Resolution 71/141 of 13 December 2016 and UNGA Resolution 73/209 of 20 December 2018 which reminds States of the ILC's recommendation for a convention and the importance of State comments on the draft Articles.

17 E.Valencia-Ospina, Eighth Report on the Protection of Persons in the Event of Disasters, U.N.Doc. A/CN.4/697, paras 412-413, E.Valencia-Ospina, Preliminary Report on the Protection of Persons in the Event of Disasters, U.N. Doc. A/CN.4/598 (May 5, 2008) para 60, E. Valencia-Ospina, Fourth Report on the Protection of Persons in the Event of Disasters, A/CN.4/643, para 25, citing UK and Russian views (A/C.6/65SR.24 \& A/C.6/65SR.23 respectively).
} 
as waiving the usual visa and customs requirements) the ILC project also considered deeper questions which raise profound questions about sovereignty such as those regarding international duties of cooperation and restrictions on disaster-affected States' rights to refuse aid,. It enquired into the imperatives that drive international disaster assistance including notions of common humanity, universal values and what might be said to define the international community. ${ }^{18}$ Interestingly, for the purposes of this paper, the draft Articles offered proclamations of solidarity and repeated invocations of concern regarding vulnerable populations. The space and opportunity thus arose for re-thinking what vulnerability means in international law, its application to disaster-affected populations generally and how notions of the 'most vulnerable' might be addressed meaningfully and creatively. However, the final instrument, despite some innovative and thoughtful inclusions, was ultimately disappointing in its attempts to approach vulnerability in a complex way. Undoubtedly the ILC's hand was restrained by the conservative nature of wider international law and hesitant approaches of States and international organisations. Nevertheless, the draft Articles' proclaimed ideology of cosmopolitan solidarity could not be fulfilled because they displayed little apparent recognition of the deep-rooted and structural nature of the diverse vulnerabilities blighting many disasteraffected populations. No space was created to take account of historical contexts, political decisions and social structures that have produced, often cumulatively, the systemic disadvantage facing some communities. The utility of the ILC's ultimately rather conservative, rhetorical invocation of vulnerability is therefore doubtful.

Vulnerability ought to be understood as more than a simple taxonomy of conditions or indicators of frailty located in particular individuals, groups or States. It should instead be recognised as a social and political product which is more than an historical phenomenon. It endures as a result of ongoing contemporary power imbalances, which themselves highlight the relational dimension to the condition of vulnerability. As will be seen from the critique of their terms, despite the ILC project's initial ambition, the draft Articles resist a more aspirational understanding of vulnerability. Consequently, the pre-eminence of certain institutions remains unquestioned, the responsibility of disaster-affected States is continually foregrounded and culturally situated notions of risk (both in terms of its creation and avoidance) are fortified.

This article ponders the possibilities existing for a deeper legal re-understanding of vulnerability in the disaster context. It argues that, via engagement with particular social science research, legal texts that more comprehensively address the plight of disastervulnerable populations, are possible. The approaches of critical geographers, historians and anthropologists who dispute the human/nature dichotomy and stress the analytical value of political ecology are of particular interest. By emphasising disasters less as geophysical events and more as 'the function of ongoing social orders as they overlie physical environments', ${ }^{19}$ political ecology reveals that certain marginalised peoples are adversely incorporated into political, social and economic relationships that produce their vulnerability, while simultaneously creating relative security for others. As a mechanism of social control and a lingua franca of international relations, international law makes potential contributions to these relational dynamics of vulnerability. An increased self-awareness of law's capacity for situational framing and operational signposting (such as that embodied in the ILC draft Articles) is therefore essential. Multi-disciplinary perspectives offer a rich reservoir from

\footnotetext{
${ }^{18}$ D. Kritsiotis, 'Imagining the International Community' (2002) 13(1) E.J.I. L. 961.

${ }^{19}$ S. Hoffman and A. Oliver-Smith The Angry Earth (Routledge 1999) 6.
} 
which lawyers can draw (while maintaining disciplinary rigour) and thereby facilitate their development of more ambitious, relevant disaster law.

In terms of argument structure, this article initially reflects upon, and critiques, the ILC's approach in addressing the issue of vulnerability in the particular context of the legal provisions protecting persons in contemporary disasters, and subsequently ponders the possibilities for greater creativity in this endeavour in disaster law. It then broadens out its analysis by investigating general conceptualisations of vulnerability in disasters, and by discussing vulnerability's positioning as a legal category. This contextualisation and conceptualisation is then blended to illustrate the varying and stratified nature of disaster vulnerability. In particular, the article analyses the different experiences of two earthquakestruck States (Haiti and Chile in 2010), as well as the experience of different communities within individual disaster-stricken States. Conscious of the need for critical reflection, the analysis then engages with those detracting from contemporary social-science conceptualisations of vulnerability. Nevertheless, the article concludes that there is an enduring value in this particular theorisation of disaster law given its potential for building capacity that takes account of structurally-produced weaknesses.

\section{THE ILC ARTICLES AND VULNERABILITY}

As the multiple instruments of varying authority testify, ${ }^{20}$ international disaster law long eluded clarification and codification. ${ }^{21}$ The multiplicity of relevant actors was also a muddling factor and further complications arose from disaster law's intersectional identity which, as noted, embraces the complex systems of human rights law, ${ }^{22}$ environmental law and armed conflict law. ${ }^{23}$ The ILC should therefore be commended for heeding the call for clearer regulation to streamline and structure a regulatory framework capable of expediting disaster assistance. ${ }^{24}$ More pertinently, the ILC drafting project seems to have picked up on wider discussions regarding law's capacity to reduce vulnerability to disasters. ${ }^{25}$ The ILC also explicitly adopts a rights-based approach ${ }^{26}$ which draws on existing human rights law. In development and poverty reduction strategies, this approach specifically urges that inequalities, discriminatory

\footnotetext{
${ }^{20}$ The 1986 Convention on Assistance in the case of a Nuclear Accident and the 1998 Tampere Convention. See the Special Rapporteur's Preliminary Report, on the pot pourri of relevant multilateral and bilateral agreements, material drafted by expert bodies such as the Red Cross, internal U.N. rules, regulations and resolutions (notably UNGA Res 46/182 of 1991), regional arrangements. See also resolutions of the UN General Assembly resolutions and political declarations. Preliminary Report, A/CN.4/598 (n 17) paras 33-35, 37 and ILC. Report Fifty-eighth Session, A/61/10 Annex C (n 14) paras 12-15. Key soft law instruments include the 1994 Mohonk Criteria for Humanitarian Assistance in Complex Emergences, the 2007 Guidelines for the Domestic Facilitation and Regulation of International Disaster Relief and Initial Recovery Assistance (the IFRC/IDRL Guidelines), the San Remo Principles (infra n 95) Oslo Guidelines on the Use of Foreign Military and Defence Assets in Disaster Relief (2007), Stockholm Principles and Good Practice of Humanitarian Donorship (2003) and the Sphere Project, Humanitarian Charter and Minimum Standards in Disaster Response.

${ }^{21}$ Despite the establishment in 1927 of the International Relief Union and treaty attempts in 1984, systematisation was unachievable, A/61/10 Annex C, (n 14) paras 18-23, K. N. Bookmiller "Closing "the yawning gap"? International disaster response law at fifteen' in Breau \& Samuel, n 4, 51. D.P. Fidler 'Disaster Relief and Governance after the Indian Ocean Tsunami: What Role for International Law?' (2005) 6 MJIL 458.

${ }^{22}$ W. Kälin 'The Human Rights Dimension of Natural or Human-made Disasters' (2012) 55 German Ybk IL 119.

${ }^{23}$ Bookmiller (n 21) 46.

${ }^{24}$ See IFRC, International Disaster Response Laws (IDRL): Project Report 2002-2003 (Dec. 2-6, 2003), ILC. Rep. Fifty-eighth Session A/61/10, Annex C (n 14) para 8, 464-465 and the Analytical Guide to the Work of the International Law Commission (June 16, 2016), http://legal.un.org/ilc/guide/6_3.shtml.

${ }^{25}$ Hyogo Framework for Action 2005-2015: Building the Resilience of Nations and Communities to Disasters (A/CONF.206/6), J.Handmer, E.Loh, W.Choong 'Using Law to Reduce Vulnerability to Natural Disasters' (2007) 14 Geo.J. on Poverty L. \& Pol'y 13.

${ }^{26}$ Valencia-Ospina, Preliminary Report., A/CN.4/598, (n 17) paras 12, 26, 51, 62.
} 
practices and unjust distributions of power be addressed. ${ }^{27}$ At the very least, the ILC's invocation of the rights-based approach seems an acknowledgment of the need to analyse root causes and utilise a longer time-frame of analysis (rather than immediately preceding geographical events). ${ }^{28}$ Ultimately, however, the rhetorical promise of the ILC draft Articles and their provisional detail produced a textual dissonance.

The ILC is free with its use of the term vulnerability in the draft Articles and their Commentaries, making 29 explicit references to the concept. Draft Article 2 anticipated the needs of particularly vulnerable people stating that

The purpose of the present draft articles is to facilitate the adequate and effective response to disasters and reduction of the risk of disasters, so as to meet the essential needs of the persons concerned, with full respect for their rights.

Concerned persons include those directly affected by a disaster, (such as those displaced) and those indirectly affected (by, for example, loss of family members). More broadly, and more interestingly for this article's purpose, it would also cover those 'likely to be affected by a future disaster, a determination to be made at the national level based on an evaluation of the persons' exposure and vulnerability'. ${ }^{29}$ This constructs vulnerability as being about risk and complements contemporary approaches favouring 'resilience strategies' and 'capacitybuilding'. ${ }^{30}$

The Special Rapporteur's eschewal of charitable notions in favour of rights ${ }^{31}$ found reflection in draft Article 4 which emphasises the need to respect and protect the inherent dignity of the human person, and draft Article 5 which stresses the need for respect and protection of the human rights of disaster-affected persons. The ILC did not list all applicable rights $^{32}$ but did highlight the right to life and the right to receive humanitarian assistance. Very interestingly, it noted that the rights of particularly vulnerable groups and the rights of communities to have a voice in the planning and execution of risk-reduction, response and recovery initiatives, and non-discrimination in obtaining durable solutions were of particular relevance. ${ }^{33}$ Despite this being contained in Article 5's somewhat general content, this gave heart to those committed to the plight of the (variously defined) vulnerable.

UNICEF had already identified the crucial need to eliminate pre-existing inequality in order to realise human rights. ${ }^{34}$ The use of human rights language (and recognition of particularly vulnerable groups) in combination with the rights-based approach, undoubtedly opened up the possibility of at least identifying the underpinning, systemic, causes of vulnerability, inequality and abuse. Further, the overtures towards the involvement of local vulnerable communities in risk-reduction, response and recovery initiatives was particularly interesting, given the potential for drawing upon indigenous adaptability practices (developed and enduring over millennia) in place of top-down technocratic, Northern, quick approaches. This was picked up in the Commentaries to draft Article 6 discussed below.

\footnotetext{
${ }^{27}$ OHCHR, Frequently Asked Questions on a Human Rights-Based Approach to Development Cooperation 15 (2006), http://www.ohchr.org/Documents/Publications/FAQen.pdf.

${ }^{28}$ H.Charlesworth, 'International Law: A Discipline of Crisis' (2002) 65(3) MLR 377.

${ }^{29}$ Draft Art 2 Commentary para 7, A/71/10 (n 13) 5.

${ }^{30}$ B.E.Aguirre 'Dialectics Of Vulnerability and Resilience' (2007) 14 Geo. J. on Poverty L.\& Pol'y 39

${ }^{31}$ Preliminary Report, A/CN.4/598 (n 17) para 12.

${ }^{32}$ Draft Article 5 Commentary para 5, A/71/10 (n 13) 13.

${ }^{33}$ Ibid 13-14.

${ }^{34}$ UNICEF Human Rights-Based Approach to Programming, http://hrbaportal.org/faq/what-is-a-human-rightsbased-approach.
} 
Draft Article 6 which outlines the guiding principles of humanity, ${ }^{35}$ neutrality and impartiality ${ }^{36}$ in any disaster response, also stresses the importance of non-discrimination while taking account of (and indeed prioritising ${ }^{37}$ ) the needs of the particularly vulnerable. ${ }^{38}$ Paragraph 7 of draft Article 6's Commentary states:

... non-discrimination is not to be taken as excluding the prospect of "positive discrimination" as appropriate. The phrase "while taking into account the needs of the particularly vulnerable" in draft article 6 reflects this position. The term "vulnerable" encompasses both groups and individuals. For this reason, the neutral expression "vulnerable" was preferred to either "vulnerable groups" or "vulnerable persons". The qualifier "particularly" was used in recognition of the fact that those affected by disaster are by definition vulnerable.

The Commentary noted that the phrase 'particularly vulnerable' reflected the landmark 2007 Guidelines of the International Federation of Red Cross Societies ${ }^{39}$, the resolution on humanitarian assistance adopted by the Institute of International Law, ${ }^{40}$ and General Assembly resolution 69/135 of 12 December 2014,which requested:

Member States, relevant humanitarian organizations of the United Nations system and other relevant humanitarian actors to ensure that all aspects of humanitarian response, including disaster preparedness and needs assessments, take into account the specific humanitarian needs and vulnerabilities of all components of the affected population, in particular girls, boys, women, older persons and persons with disabilities, including in the design and implementation of disaster risk reduction, humanitarian and recovery programming and post-humanitarian emergency reconstruction, and in this regard encourages efforts to ensure gender mainstreaming ... ${ }^{41}$

The ILC Commentaries then explain that the ILC decided against the inclusion of a list of vulnerable groups within draft Article 6 in recognition of the relative nature of vulnerability. Fixed iterations of particularly vulnerable subgroups of individuals within disasteraffected/prone populations were less important than recognising that the principle of nondiscrimination includes the positive obligation to give specific attention to the needs of the particularly vulnerable.

The term 'particularly vulnerable' was thus left deliberately open-ended to include not only the categories of individuals usually associated with the concept, but also other possible individuals potentially finding themselves particularly vulnerable post-disaster, such as nonnationals. Although this was potentially simply an invitation to further generality, the ILC's recognition suggested an agile, contextually sensitive understanding of vulnerability which was nuanced and welcome. This sensitivity further extended to the ILC's urgings that vulnerable groups be engaged in the design, implementation, monitoring and evaluation, and assistance provided in the event of a disaster, as well as in preparing for possible disasters. As noted, this had appeared in the Commentaries to draft Article 5 and as well as stressing the practical

\footnotetext{
${ }^{35}$ ILC. Report Fifty-eighth Session A/61/10 Annex C, n.14 para 34, 478-480 ' $\left.\mathrm{h}\right] \mathrm{hman}$ suffering is to be addressed wherever it exists, and the dignity and rights of all victims should be respected and protected'.

${ }^{36}$ Whereby provision of humanitarian assistance is based on needs assessment, A/61/10 Annex C (n 14) para 34, 478-480.

${ }^{37}$ Draft Art 6 Commentary para 5 A/71/10 (n 13). See also, U.N. Doc. A/66/10, (n 15) 254.

${ }^{38}$ Draft Art 6 Commentary para 5, A/71/10 (n 13).

392007 Guidelines for the Domestic Facilitation and Regulation of International Disaster Relief and Initial Recovery Assistance (the IFRC/IDRL Guidelines) Article 4, para 3(a).

${ }^{40}$ See Article II para. 3 of the Inst. of Int'l Law, Resolution on Humanitarian Assistance (Sept. 2, 2003), [hereinafter Bruges Resolution].

${ }^{41}$ General Assembly resolution 69/135 of 12 December 2014, para 32
} 
importance of vulnerable group involvement, it also suggested an awareness of likely preexisting isolation from such decision-making processes. ${ }^{42}$

Paragraph 9 of the Commentaries to draft Article 6 further honed in on the issue of gender vulnerabilities, noting that women and girls are often disproportionately affected and exposed to risks, including increased loss of life and livelihoods, and gender-based violence, during and after disasters. This cross-referenced the Hyogo Framework ${ }^{43}$ and in particular invoked Article 19(d) of the Sendai Framework for Disaster Risk Reduction 2015-2030 as a fruitful strategy which more broadly notes that

Disaster risk reduction requires an all-of-society engagement and partnership. It also requires empowerment and inclusive, accessible and non-discriminatory participation, paying special attention to people disproportionately affected by disasters, especially the poorest. ${ }^{44}$

Specific reference is also made to the importance of a 'gender, age, disability and cultural perspective in all policies and practices' and that 'special attention should be paid to the improvement of organized voluntary work of citizens'. All of this seemed very hopeful as regards a dynamic approach to vulnerability. This twin-pronged imperative of addressing gender vulnerability post-disaster ${ }^{45}$ and reducing the vulnerability to, or likelihood of becoming, a disaster-prone population (producing intense vulnerability for some sections) casts vulnerability in this context as a matter of both discrimination and risk-assessment. This leads on nicely to draft Article 9 and its commentary which also addresses vulnerability in terms of risk.

Draft Article 9 notes the obligations of States to reduce disaster risks via appropriate measures, including through legislation and regulation, to prevent, mitigate, and prepare for disasters. ${ }^{46}$ Paragraph 2 of the draft Article iterates the conduct of risk assessments, the collection and dissemination of risk and past loss information, and the installation and operation of early warning systems as exemplars. The commentary ${ }^{47}$ notes the growing recognition of a legal obligation to prevent and reduce of the risk of disaster, encompassing risk assessments, the establishment of early warning systems, and the right to access risk information. ${ }^{48}$ This seeks to achieve a substantial reduction of disaster risk and losses in lives, livelihoods and health, and in the economic, physical, social, cultural and environmental assets of societies generally, and to strengthen resilience. By invoking the Sendai Framework, the ILC commentary stresses the importance of a multifaceted approach, specifically cites the crucial role of structural measures and makes reference to integrated and inclusive cultural approaches. Again, such cross-references heartened actors wishing to operationalise initiatives which move beyond symptomatic approaches. However, although the Framework offered

\footnotetext{
42 Draft Art 5 Commentary para. 8, A/71/10 (n 13).

43 Action 2005-2015: Building the Resilience of Nations and Communities to Disasters A/CONF.206/6 and Corr.1, chap. I, resolution 2, para 13 (d).

44 Third UN World Conference on Disaster Risk Reduction in Sendai, Japan, on March 18, 2015, https://www.unisdr.org/files/43291_sendaiframeworkfordrren.pdf. See broadly para 16 which stresses disaster prevention and reduction via strategies involving economic, structural, legal, social, health, cultural, educational, environmental, technological, political and institutional measures.

45 See also J.Fowler 'Empower women to reduce disaster risk', 8 March 2017, https://www.unisdr.org/archive/52264.

${ }^{46}$ For an account of this terrain, B.Nicoletti, 'The Prevention of Natural and Man-Made Disasters: What Duties for States?' in A. de Guttry, M. Gestri and G. Venturini (eds) International Disaster Response Law (T.M.C. Asser 2012) 177.

${ }^{47}$ Draft Art 9 Commentary, A/71/10 (n 13) para 3.

${ }^{48}$ Global Platform for Disaster Risk Reduction in 2013, fourth session, Geneva, 19-23 May 2013.
} 
benefits to the ILC (which could not credibly have ignored its terms given its reflection in regional, multilateral and bilateral disaster risk/reduction agreements and national programmes ${ }^{49}$ ) it also had a restricting influence in that the Framework actually nudged the draft Articles' approach to operationalisation in an orthodox direction. This is evident in the measures iterated in paragraph 2 of draft Article 9 which reflect the Sendai Framework. ${ }^{50}$

Paragraph 3 of draft Article 9's commentary ${ }^{51}$ also references the particular term of the Sendai framework which stresses that

Each State has the primary responsibility to prevent and reduce disaster risk, including through international, regional, subregional, transboundary and bilateral cooperation. The reduction of disaster risk is a common concern for all States and the extent to which developing countries are able to effectively enhance and implement national disaster risk reduction policies and measures in the context of their respective circumstances and capabilities can be further enhanced through the provision of sustainable international cooperation. ${ }^{52}$

By stressing the dispersal of disaster-risk reduction responsibilities, criticisms that Draft Article 9's perspective is harsh as regards the responsibilities of disaster-vulnerable States might be stifled. The Sendai Framework's urgings that capacity-building responsibilities can be enhanced by actors within the wider international community might even suggest a recognition of relational vulnerabilities. However, the credibility of this position is disputable. First, the phraseology suggests the 'discovery' of incapable States rather than their production. Secondly, the Framework notes these States are viewed as hazards not just towards their own people but for the wider international community - indeed this risk towards others is textually prioritised over capacity-building. Finally, Sendai's terminology clearly leaves open the possibility for 'remedial' approaches towards disaster-affected States without any acknowledgement of potentially useful and informative local or indigenous practices. Thus, not only are contextualised adaptation practices not favoured, there is not even an allusion to them. This lack of imagination persists in subsequent commentaries to draft Article 9. Paragraph 15 continues that the state obligation

... "to prevent, mitigate, and prepare for disasters", serves to describe the purpose of the "appropriate" measures that States are to take during the pre-disaster phase to address exposure, vulnerability and the characteristics of a hazard, with the ultimate goal of reducing disaster risk. ....

Thus, between draft Articles 6 and 9 there is a shift from recognising the plight of vulnerable communities in broad terms to a far narrower series of scientific and technical options. The discourse of addressing vulnerability shifts to one of risk, and emphasises national responsibilities. Whilst it might be argued that the national focus is alleviated by the duty to co-operate outlined in draft Article $7,{ }^{53}$ this duty has also been critiqued as focusing on duties of disaster-affected States rather than external actors. ${ }^{54}$ Further, draft Article 8, which outlines forms of co-operation, focuses on a post-disaster scenario and stresses technical and logistical

\footnotetext{
${ }^{49}$ Draft Art 9 Commentary, paras 5 and 6, A/71/10 (n 13).

${ }^{50}$ Ibid para 17.

${ }^{51}$ Ibid para 3.

52 Sendai Framework (n 44) para 19(a).

53 'In the application of the present draft articles, States shall, as appropriate, cooperate among themselves, with the United Nations, with the components of the Red Cross and Red Crescent Movement, and with other assisting actors.'

${ }^{54}$ T. O'Donnell, \& C. Allan (n 4) and T. O'Donnell, \& C. Allan, 'Identifying solidarity: the ILC project on the protection of persons in disasters and human rights' (2016) 49(1) Geo. Wash. Int'l L. Rev. 53.
} 
assistance. ${ }^{55}$ Thus, there is no place for social scientific enquiry. The responsibility of a disaster-vulnerable State is stressed, and forms of co-operation for external actors are firmly located post-disaster and narrow in form.

As noted, draft Article 9 stresses the importance of disaster-preparedness and corresponding State obligations. Paragraph 18 of its commentaries outlines structural and nonstructural measures including community-level preparedness and education; the establishment of disaster risk governance frameworks; contingency planning; setting-up of monitoring mechanisms; land-use controls; construction standards; ecosystems management; drainage systems; social safety-nets addressing vulnerability and resilience; risk disclosure; riskinformed investments; and insurance. Although these represent responses to circumstances commonly understood to increase a population's vulnerability ${ }^{56}$ they also show the draft Articles adopting traditional 'diagnosis' and 'corrective' approaches in characterising and addressing vulnerability. As well as foregrounding the agency of disaster-exposed states they narrowly characterise how vulnerability manifests itself.

This spotlighting represents a practice-based analysis of vulnerability, suggests technocratic and administrative solutions, and sidesteps consideration of the underlying context or causes of those practices. Practices of poor investment or corruption are not organic phenomena: they are, rather, political and social products which tend to result from the actions, over time, of both internal and external actors. Further, the remedial routes proposed make no mention of traditional adaptation or natural resource management practices. They do, however, privilege approaches prevailing in Global North industrialised societies. Although the suggestions itemised in draft Article 9's Commentaries may be open to capturing local, ancestral approaches, they may not in fact do so. Such doubtfulness unfortunately, and probably unintentionally, lends a remote, reformative tone to the draft Articles which potentially alienates intended audiences ${ }^{57}$ - a general problem bedevilling international law. ${ }^{58}$ It also fails to displace notions that catastrophes are also social disasters which reveal societal choices and the prioritisation of some interests and lives over others. ${ }^{59}$

The final commentaries to draft Article 9 offer a mixed bag of comfort to those seeking a more thoughtful perspective on vulnerability. Risk assessments which compel a closer look at local realities and local community engagement are stressed. These are considered indispensable to effective understandings of circumstances, factors and characteristics of disasters and appropriate responses. The collection and dissemination of information concerning risk and past loss is also highlighted as crucial on the basis that free availability of such information allows for stakeholder responsibility and 'informed determination of priorities for planning and investment purposes' as well as enhancing transparency in transactions and public scrutiny and control. So, although there is attention given to the issue of grass-roots information and local, vulnerable community engagement, the entirety of draft Article 9 sees these approaches through a technological lens where the emphasis is on local agency rather than informed international co-operation and responsibility.

\footnotetext{
${ }^{55}$ Such as humanitarian assistance, coordination of international relief actions and communications, and making available relief personnel, equipment and goods, and scientific, medical and technical resources. See also draft Art 16 regarding an affected State's duties to protect of relief personnel, equipment and goods.

${ }^{56}$ For example, insufficient/corrupt building practices (see the examples of earthquakes in Turkey and China, notably in Szechuan in 2008) lax health and safety processes and safeguards (Oneryildiz v Turkey (2005) 41 EHRR 20); poor infrastructure, and poorly-resourced health services.

${ }^{57}$ T. Franck The Power of Legitimacy Among Nations (OUP 1990).

${ }^{58}$ H. Charlesworth (n 28).

${ }^{59}$ D.Nix-Stevenson 'Human Response to Natural Disasters' (2013) July-September SAGE Open 1.1.
} 
It is submitted, that an effective disaster or risk mitigation strategy needs to take account of the reality that for some States and communities, events, including historical ones, accumulate and produce complex, volatile vulnerabilities - just as they produce and embed strengths for other States. Disaster law is newly emerging and the ILC project offered an opportunity for innovative approaches. There was scope for formally acknowledging obligations to consult with indigenous communities regarding adaptation practices. Nuanced thinking about what a 'marginalised' community looks like could have been pondered (and possibly accompanied by international obligations of affirmative co-operation). A re-thinking of what international co-operation looks like in a disaster context was also possible. Reorienting differentiated duties of external actors to offer assistance in mitigation measures and disaster assistance (particularly as regards relationships between former empires and colonial peoples) could have been an option. The possibility for drafting a legal instrument that moved beyond a one-size-fits-all managerial, scientific approach, and the terms of which might allow space for acknowledging how historical, social, cultural and political contingencies conspire to produce vulnerabilities and apparent lack of resilience, was exciting. However, the tentative overtures towards such innovation disappeared almost immediately and the orthodox approach was reinforced. Nevertheless, there remains potential for pursuing new approaches.

\section{VULNERABILITY IN DISASTERS}

In the disaster context, vulnerability may be framed in different ways. For example, certain States are considered more vulnerable than others due to their geography, their poverty or their political systems. Respective examples are as follows. The earthquake that devastated Nepal in 2015 , killing more than 8,000 people, led to scientific studies suggesting a regional fault line's kink had created a sub-surface ramp thereby raising the height of the mountains. ${ }^{60}$ The discourse following the 2010 earthquake in Haiti widely attributed the utterly catastrophic effects as being intensified by Haiti's pre-existing poverty. After Cyclone Nargis struck in $2008,{ }^{61}$ the military regime in Myanmar was accused of aggravating the population's suffering through its autocratic suspicions towards international assistance. Very often a mixture of such factors is blamed. For example mismanagement, limited financial resources, lack of skills and corruption are identified as aggravating factors in disasters, as seen in the case of Indonesia's disaster-prone history. ${ }^{62}$ A particularly unpleasant discourse blames Africa's weak governments and economies, famines and disease on its post-1960 leadership without acknowledging how 'the fragility of contemporary Africa is a direct consequence of two centuries of slaving, followed by another of colonial despotism'. ${ }^{63}$

Within States, further stratification of vulnerability occurs with certain communities appearing more exposed than others. ${ }^{64}$ In the Concluding Observations on the third periodic report of Japan, the UN Committee on Economic, Social and Cultural Rights (UNCESCR) noted the complexity of relief response to the 2011 Great East Japan Earthquake and tsunami, and the Fukushima nuclear accident, but at the same time it expressed concern that the specific

\footnotetext{
60 J.R.Elliott, R.Jolivet, P.J.González, J.-P.Avouac, J.Hollingsworth, M.P.Searle \& V.L.Stevens, 'Himalayan megathrust geometry and relation to topography revealed by the Gorkha earthquake' (2016) 9 Nature Geoscience, 174.

61 'Cyclone Disaster, 01, May 2008', Keesing's Record of World Events (1931-2015) (2008), Vol.54 (5) (May), 48576.

62 'Natural Disasters in Indonesia' https://www.indonesia-investments.com/business/risks/naturaldisasters/item243? 'Indonesia tsunami relief efforts hit by infrastructure problems' Financial Times September 30, 2018, 'A tsunami strikes a poor part of Indonesia' The Economist 30 September 2018.

${ }^{63}$ R. Drayton 'The wealth of the west was built on Africa's exploitation', The Guardian 20 August 2005.

${ }^{64}$ J. Purdy 'The Unequal Distribution of Catastrophe in North Carolina', The New Yorker 18 September 2018.
} 
needs of disadvantaged and vulnerable groups, such as older persons, persons with disabilities, and women and children, were not sufficiently met either during the evacuation or in the rehabilitation and reconstruction efforts: this raised concerns as to whether there had been full observance of Articles 11, 2(2) International Covenant on Economic, Social and Cultural Rights (ICESCR). ${ }^{65}$

The UNCESCR's taxonomic articulation of vulnerabilities reflects law's traditional approach which considers certain situations or personal categories as deserving special attention and protection ${ }^{66}$ given past and ongoing prejudice and disadvantage. For example, in disasters, discrimination in relation to food-access is problematic, ${ }^{67}$ and despite severe resource constraints, particularly vulnerable groups within beleaguered populations ${ }^{68}$ may need 'priority consideration', in accessing food. ${ }^{69}$ Vulnerable categories might include inter alia gender, race, age ${ }^{70}$ and disability. ${ }^{71}$ However, notwithstanding the increased proliferation of such groupings (and the awareness of inter-twined and cumulative disadvantage via intersectionality studies), there are certain situations or identities of precarity which often elude law's easy reach. Poverty and post-colonialism, for example, are often addressed in an indirect fashion (if at all). It is thus unsurprising that law has seriously struggled to cope with more multi-dimensional and multi-layered versions of vulnerability such as were highlighted not only in Haiti in 2010, but also for example, in the 2005 aftermath of Hurricane Katrina, ${ }^{72}$ when the marginalisation and multiple disadvantages faced by African-American communities in the Louisiana area attracted national and international concern. Despite these traditional shortcomings of legal approaches to the rights of disaster-stricken peoples, some hopes were raised by the recommendation in 2006 for a disaster-focussed research project to be entered onto the agenda of the ILC. ${ }^{73}$

The draft Articles' preamble states that the project was mindful of the fundamental value of solidarity in international relations and the importance of strengthening international cooperation in respect of all phases of a disaster. The project's conceptual framework was thus established and the Special Rapporteur readily drew on extracts from the writings of Emer de Vattel ${ }^{74}$ to highlight the plight of disaster-stricken peoples and the imperative to offer them assistance.

The underlying principles in the protection of persons in the event of disasters are those of solidarity and cooperation, both among nations and among individual human beings. It is in

\footnotetext{
${ }^{65}$ UN Committee on Economic, Social and Cultural Rights, Concluding Observations on the Third Periodic Report of Japan, E/C.12/JPN/CO/3, para 24.

${ }^{66}$ For example see the preamble to the Paris Agreement under the United Nations Framework Convention on Climate Change, which notes that parties should, when taking action to address climate change, respect, promote and consider their respective obligations on human rights, the right to health, the rights of indigenous peoples, local communities, migrants, children, persons with disabilities and people in vulnerable situations.

${ }^{67}$ (including discrimination based on political opinion) ibid para 18.

${ }^{68}$ UN Doc. A/CN.4/SR.3054, 19, UN Doc. A/65/10, para 312. See Article II(3) of the Bruges Resolution ( $\mathrm{n} 40$ ).

${ }^{69}$ E/C.12/1997/8 para 13 See also Art 23 of Geneva Convention IV 1949 which mandates that all parties allow 'free passage of all consignments of essential foodstuffs, clothing and tonics intended for children under fifteen, expectant mothers and maternity cases'.

701989 Convention on the Rights of the Child Arts 6, 24(2) and 27.

${ }^{71}$ Art 11 of the 2006 International Convention on the Protection and Promotion of the Rights and Dignity of Persons with Disabilities obliges States, in consonance with their existing international obligations, to ensure the protection and safety of such persons in risky situations, including natural disasters.
}

72 'UN offers help to US in aftermath of Hurricane Katrina's devastation', https://news.un.org/en/story/2005/09/151082-un-offers-help-us-aftermath-hurricane-katrinas-devastation.

${ }^{73}$ ILC Report, Fifty-eighth Session, U.N. Doc. A/61/10 (n 14).

${ }^{74}$ Valencia-Ospina Preliminary Report, (n 17) para 14. 
the solidarity inspired by human suffering that the Commission's mandate finds telos, as an expression of our common heritage in a global context. ${ }^{75}$ [emphasis added]

Thus, the project's apparent raison d'être was to heed the needs of the most vulnerable disaster populations. Indeed, as noted earlier, draft Article 2 stressed the project's focus of facilitating adequate and effective responses to disasters and disaster risk-reduction, so as to meet the essential needs of the persons concerned, and indicated in its commentary that the rights of particularly vulnerable groups would have special protection and assistance. ${ }^{76}$

Vattel's expression of solidarity pre-supposed vulnerability. In the $18^{\text {th }}$ century famine represented a clear case of vulnerability while solidarity equalled external assistance. ${ }^{77}$ It is entirely plausible that Vattel's writings in $1758^{78}$ were influenced by the international assistance offered in the wake of the 1755 Lisbon earthquake and tsunami. ${ }^{79}$ In any event, in 2006 the way opened for the ILC to develop its own $21^{\text {st }}$ Century understanding of vulnerability. That this offered an opportunity for a dynamic and progressive conceptualisation which could take account of a longer, historical view and achieve a deeper analysis and recognition of embedded inequality, and the root causes of marginalisation and social vulnerability, ${ }^{80}$ was appealing. A move away from a scientific, physicalist approach to disasters (discussed subsequently) towards a more richly nuanced and sensitive social-scientific analysis seemed possible

However, the ILC project was disappointing. For one thing, Vattelian notions of uncritical, unconditional aid-provision were not forthcoming. States clearly expressed a position not only that there was no duty for external States to provide, or even offer, aid to disaster-stricken States and but indeed that such a duty's development would be unwelcome. ${ }^{81}$ This position was reflected in draft Article 12. The ILC also conceptually entwined solidarity and reciprocity by cross-referencing disaster-assistance, duties of cooperation ${ }^{82}$ and duties of disaster-struck territories not to refuse aid arbitrarily. ${ }^{83}$ This could have conveyed the ILC's stance in solidarity with vulnerable disaster-struck populations, rather than their (sometimes negligent/oppressive) home States. However, the draft Articles noted that their particular focus was on the relevant rights and obligations of States in relation to one another, with the rights and obligations of States in relation to persons in need of protection being contemplated only

\footnotetext{
75 E. Valencia-Ospina Second Report on the Protection of Persons in the Event of Disasters, U.N. Doc. A/CN.4/615, para 50 .

${ }^{76}$ Draft Art 2 Commentary, A/71/10 (n 13) para 6

77 ،... [i]f a Nation is suffering from famine, all those who have provisions to spare should assist it in its need, without, however, exposing themselves to scarcity .... To give assistance in such dire straits is so instinctive an act of humanity that hardly any civilized Nation is to be found which would absolutely refuse to do so .... Whatever be the calamity affecting a Nation, the same help is due to it'. III E. de Vattel, The Law of Nations or the Principles of Natural Law Applied to the Conduct and to the Affairs of Nations and of Sovereigns (Charles G. Fenwick trans., Carnegie Inst. of Wash. 1916) (1758), 115

78 ' $[$ W] hen the occasion arises, every Nation should give its aid to further the advancement of other Nations and save them from disaster and ruin, so far as it can do so without running too great a risk.' Vattel ibid ; see also Int'l Law Comm'n, Fifty-eighth Session, Annex C, U.N. Doc. A/61/10, (n 14) para 18, 472.

79 See Bookmiller (n 21) 46, 48, and P. Walker, D.G. Maxwell Shaping the Humanitarian World, (Routledge 2008).

${ }^{80}$ F. Fatemi, A.Ardalan, B. Aguirre, N. Mansouri, I. Mohammadfam, 'Social Vulnerability Indicators in Disasters: Findings from a Systematic Review' (2017) 22 International Journal of Disaster Risk Reduction 219. ${ }^{81}$ E.Valencia-Ospina, Fifth Rep. on the Protection of Persons in the Event of Disasters, U.N. Doc. A/CN.4/652, paras. 81, 52, 68; Int'l Law Comm'n, Rep. on the Work of Its Sixty-Fourth Session, para 57, U.N. Doc. A/67/10, at 86 (2012), Valencia-Ospina Eighth Rep., (n 17) A/CN.4/697, 74-78.

${ }^{82}$ Draft Art 7, A/71/10, (n 13).

${ }^{83}$ Draft Art 13(2), A/71/10 (n 13).
} 
'in general terms' ${ }^{84}$ Indeed, draft Article 12 simply itemised the possibility for external actors to offer assistance (at their own initiative). This crumbling of the edifice of solidarity inevitably signalled a co-extensive diminution in the conceptual power and potential of 'vulnerability'.

Of course, the Draft Articles alone could not tackle massive issues of ingrained disadvantage, colonialism and the global inequalities between States. However, it is worth recapping on Draft Article 2's claims and questioning how effective disaster responses are facilitated and risks reduced without at least acknowledging histories and directing decision-makers towards addressing the systematic nature of community vulnerability. Failing to do so somewhat challenges 'new governance' strategies ${ }^{85}$ which stress local participation. ${ }^{86}$ It perpetuates flawed disaster management practice and allows for business as usual. The following section illustrates how law has traditionally approached the question of vulnerability and the impact of that tradition upon disaster law. Thereafter it will be illustrated how unhelpful such orthodox approaches have been in facilitating a meaningful comparative analysis of different disaster incidents.

\section{VULNERABILITY AS A LEGAL CATEGORY}

Vulnerability appears both as a category and a discourse in law, and the category's width is explained by the proliferation of affected groups thought to fall within it. Vulnerability's 'subcategories' could include discrimination (affecting for example lower caste members, refugees ${ }^{87}$, national and ethnic minorities, ${ }^{88}$ migrant workers, ${ }^{89}$ indigenous peoples, ${ }^{90}$ and disease victims and orphans ${ }^{91}$ ) criminalisation, by-products of elite malpractice (for example, war) and 'organic'/bad luck victims (such as natural disasters). Indeed international human rights law and international humanitarian law (IHL) specifically identify the need to protect vulnerable populations such as children, nursing mothers, victims of sexual/gender violence, ${ }^{92}$ the elderly and the disabled. However, despite beneficent intentions, compartmentalising and 'snapshotting' vulnerability avoids systematic analysis. The application of IHL principles to disasters illustrates this folly.

Civilian vulnerability is specifically acknowledged in IHL. Indeed the 'cardinal principle' of distinction safeguards the general position of civilians and particular provisions

\footnotetext{
${ }^{84}$ Draft Art. 1 Commentary, para. 3, A/71/10 (n 13).

${ }^{85}$ S.F. Ali, Governing Disasters: Engaging Local Populations in Humanitarian Relief (CUP 2016). 54-60, 73-75

${ }^{86}$ O. Bakewell 'Uncovering Local Perspectives on Humanitarian Assistance and Its Outcomes' (2000) 24(2) Disasters 103

87 G.Alfredsson and P.Macalister-Smith (eds.) The Living Law of Nations: essays on refugees, minorities, indigenous peoples and the human rights of other vulnerable groups in memory of Atle Grahl-Madsen. (Engel 1996). C.L.Reyes 'Gender, Law, and Detention Policy: Unexpected Effects on the Most Vulnerable Immigrants' (2010) 25 Wis. J.L. Gender \& Soc'y 301. See also L.A.Fisher Flores "Protecting the Vulnerable Among Us" Notario Fraud and a Private Right of Action under the Texas DTPA' (2015) 19 J.Consumer \& Com.L. 28.

${ }^{88}$ Y. Dausab 'Access to Justice: The Use of International Law Clinics to Advance the Case for Vulnerable Members of Society' (2011) 6 Md.J.Int'lL 8, J. Padilla 'Lawyering Against Power: The Risks Of Representing Vulnerable And Unpopular Communities' (2012) 11 Seattle J. for Soc. Just. 173, C.Wilke \& P.Willis 'The Exploitation of Vulnerability: Dimensions of Citizenship and Rightlessness in Canada's Security Certificate Legislation' (2008) 26 Windsor Y.B. Access to Just. 25.

${ }^{89}$ N. Misra 'The Push \& Pull of Globalization: How the Global Economy Makes Migrant Workers Vulnerable to Exploitation' (2007) 4(3) Hum.Rts.Brief 2.

${ }^{90}$ K. McNeil 'The Vulnerability of Indigenous Land Rights in Australia and Canada' (2004) 42 Osgoode Hall L.J. 271.

${ }^{91}$ C.Levine $A$ Death in the Family: Orphans of the HIV Epidemic, (ed.) (UHF 1993).

921998 International Criminal Court Statute Article 68(1) and Article 43 regarding the Victims and Witnesses Unit (VWU). 'The U.N. Security Council's Arria-Formula Meeting on Vulnerable Groups in Conflict: ISIL's Targeting Of LGBTI Individuals’ (2016) 48 N.Y.U. J. Int'l L. \& Pol. 1191.
} 
guard against civilian starvation. Rule 55 of the ICRC IHL Customary Study articulates, as a customary norm, that in both international and non-international armed conflicts, parties to the conflict must allow and facilitate rapid and unimpeded passage of humanitarian relief for civilians in need, which is impartial in character and conducted without any adverse distinction. ${ }^{93}$ In particular, national Red Cross and other relief societies should 'be able to pursue their activities' without obstruction or interference. ${ }^{94}$ Under Article 59 of Geneva Convention IV, if an occupied territory is 'inadequately supplied,' the Occupying Power shall agree to relief schemes, facilitating them 'by all the means at its disposal'. Principle 3 of the 1993 San Remo Guiding Principles on the Right to Humanitarian Assistance ${ }^{95}$ states that a right to humanitarian assistance may be invoked when essential humanitarian needs in emergencies are unmet, and their abandonment threatens human life or gravely offends human dignity. ${ }^{96}$ IHL rules exerted considerable influence on the ILC project and the Special Rapporteur saw the principle of humanity acting as a meeting point between international humanitarian law and international human rights law. As an expression of general values, it guides international legal regulation overall.

Given its virtuous tone, the allure of IHL's key principle of humanity is almost irresistible. However, its invocation in the disaster context is not unproblematic. First, as noted elsewhere ${ }^{97}$ in international armed conflict sovereignty has already been ruptured, which is not necessarily the case in disasters. Secondly, there is a ratione temporis to IHL's application - it lasts as long as the conflict lasts. ${ }^{98}$ Once over, this particular application of 'vulnerability law' terminates. In a peacetime disaster context, vulnerability is a much more elusive and contested concept and part of a much longer time-frame, particularly when multiple disasters stockpile to compound a population's vulnerability. ${ }^{99}$ Arguably, IHL assisted only with certain aspects of the ILC project's drafting, notably regarding the duty not to refuse aid arbitrarily (which has been critiqued ${ }^{100}$ ). IHL also limits understandings of vulnerability by focussing on immediacy. It thereby sets up narrow expectations such as the relief of immediate starvation and poor sanitation, favouring triage over more holistic measures which address and remedy embedded vulnerabilities. The bigger issue of structural inequality of communities is seemingly left aside despite its importance. This is illustrated in the following section.

\footnotetext{
93 J-M.Henckaerts and L.Doswald-Beck Customary International Humanitarian law Vol I: Rules (Cambridge: CUP 2005) (ICRC Study). For particular detail on specific treaty provisions see Art 23 of Geneva Convention IV, Art 70(2) of Additional Protocol I, Art 18(2) of Additional Protocol II, and UN Security Council Resolution 1296(2000). The 2005 ICRC customary study also maintained that host States must not refuse assistance from humanitarian organisations 'on arbitrary grounds, 197. More generally, Art 30 Geneva Convention IV allows protected persons to make aid-applications to the ICRC, national associations and any assisting organisation. Art 38 provides that protected persons should be enabled to receive relief sent to them. Art 60 Geneva Convention IV, generally prohibits occupying powers from diverting relief consignments from their intended purposes (see also Arts $61 \& 62)$.

94 Geneva Convention IV Art 63.

95 International Institute of Humanitarian Law, 'Guiding Principles on the Right to Humanitarian Assistance' (1993) 33 (297) International Review of the Red Cross , 521,

${ }^{96}$ See also Principle 6 which notes that in the event of refusal of either offers of assistance, or access to the victims when humanitarian access is agreed upon, State and organisations concerned may 'undertake all necessary steps to ensure such access' according to humanitarian and human rights principles.

97 C. Allan \& T. O’Donnell 'A Call to Alms?: Natural Disasters, R2P, Duties of Cooperation and Uncharted Consequences' (2012) 17(3) J. of Conf. \& Secur. L. 337.

981949 Geneva Conventions Common Arts 2 and 3 and Additional Protocols I and II.

${ }^{99}$ M. Moseley 'Convergent Catastrophe: Past Patterns and Future Implications of Collateral Natural Disasters in the Andes' in Hoffman \& Oliver-Smith (n 19) 59.

${ }^{100}$ T. O'Donnell \& C. Allan 'An Offer You Cannot Refuse? Natural Disasters, the Politics of Aid Refusal and Potential Legal Implications’ (2013) 5(1) Amsterdam Law Forum 36.
} 


\section{DISASTERS, VARYING VULNERABILITIES AND HISTORY}

Rights to life, ${ }^{101}$ food, health/medical services, water supplies, adequate housing, clothing and sanitation, and protection from discrimination are jeopardised in disasters. ${ }^{102}$ However, when disaster strikes, it is intuitively perceived as Nature's great leveller. The 2004 Indian Ocean Boxing Day tsunami is a paradigm case illustrating harm to both rich and poor. The 2011 Great East Japan earthquake/tsunami ${ }^{103}$, the 2011 Christchurch earthquake, the 2009 and 2016 earthquakes in the Italian towns of L'Aquila and Amatrice, and the regular concerns regarding instances of flooding in the UK, all testify to the territorial precariousness of even the most wealthy, developed States. Globalisation's advent and increased notions of inter-dependence have also intensified impressions of mutual vulnerability. ${ }^{104}$ Some thinkers have suggested reconsidering vulnerability less as a state of precarity and more as an inevitability for all. ${ }^{105} \mathrm{In}$ the international context, this perspective potentially offers an escape portal from the hegemony suggested by 'invulnerability'. Disasters certainly strike irrespective of the socio-economic profile of a country and can have devastating effects. However, undoubtedly, populations enduring pre-existing hardships are more susceptible to increased harm in disasters ${ }^{106}$ than are more privileged populations. This may be illustrated by comparing the 2010 earthquakes in Chile and Haiti.

\section{A. 2010 Earthquakes}

On February 2010, at 03.34am, an earthquake with a magnitude of 8.8, occurred off the coast of central Chile. ${ }^{107}$ Approximately 521 fatalities were confirmed, with 56 people missing, presumed dead, in the tsunami that followed. Several factors were identified as potentially contributing overall to the low casualty rate and rapid recovery. A strong building code was comprehensively enforced. Legal provisions held building owners accountable for losses in buildings they built for 10 years. The American Red Cross noted that the limited number of fires after the earthquake may have been due to the early shutdown of the electricity grid. Coordinated, local emergency responses were very effective and emergency management, fire, and police were empowered to respond without communication with the capital. Finally, the overall high levels of population knowledge about earthquakes and tsunamis were considered to have aided post-event responses. ${ }^{108}$

One month before the Chilean incident, Haiti endured an earthquake with a magnitude of 7.3. Death toll estimates varied anywhere from 220,000 to 316,000 . Approximately 1.5

\footnotetext{
${ }^{101}$ International Covenant on Civil and Political Rights (ICCPR), 1966, Art 6, see also 'Natural Disaster: mudslide - positive obligations - arts 2, 13 and art.1 of Protocol 1' (2008) 4 E.H.R.L.R. 541, M. Stallworthy, 'Human rights challenges and adequacy of State responses to natural disaster', (2009) 11(2) Env. L. Rev. 123 and S. Ford 'Is the Failure to Respond Appropriately to a Natural Disaster a Crime Against Humanity? The Responsibility to Protect and Individual Criminal Responsibility in the Aftermath of Cyclone Nargis' (2010) 38 Denv. J.Int'l L.\& Pol'y 227.

102 ICESCR Arts 11, 12, 14(2), R. Barber, 'Protecting the right to housing in the aftermath of natural disaster: standards in international human rights law', (2008) 20(3) I.J.R.L. 432 and Article 2 of both ICESCR and ICCPR. 103 B. Oskin, Japan Earthquake \& Tsunami of 2011: Facts and Information, LiveScience.com (May 7, 2015), http://www.livescience.com/39110-japan-2011-earthquake-tsunami-facts.html.

${ }^{104}$ O. Aginam 'From Isolationism to Mutual Vulnerability and Back: International Law and Unfair Distribution of Global Disease Burdens' (2001) 95 Am. Soc'y Int'l L. Proc. 58.

105 M. Fineman 'Vulnerability and Inevitable Inequality' (2017) 4 Oslo Law Review, 133, A. MacIntyre, Dependent Rational Animals, (Bloomsbury 2009).

${ }^{106}$ Mary Crock 'The Protection of Vulnerable Groups' in Breau \& Samuel (n 4) 383, 383-387.

107 'Massive earthquake strikes Chile' http://news.bbc.co.uk/1/hi/8540289.stm.

${ }^{108}$ Report on the 2010 Chilean Earthquake and Tsunami Response by the American Red Cross Multidisciplinary Team, https://pubs.usgs.gov/of/2011/1053/.
} 
million people were initially displaced, ${ }^{109}$ and about 500,000 remained homeless in 2014. ${ }^{110}$ Even before the earthquake, Haiti was one of the poorest countries in the world and the poorest in the Western hemisphere. It ranked 145 out of 169 countries in the UN Human Development Index (Chile ranked $45^{\text {th }}$ in the 2010 rankings ${ }^{111}$ ). Over 70 per cent of the population was living below the poverty line ${ }^{112}$ with 54 per cent in abject poverty. Two-fifths of all Haitians were subsistence farmers. ${ }^{113} 86$ per cent of people in the capital city of Port-au-Prince were living in slum conditions - mostly tightly-packed, poorly-built, concrete buildings. ${ }^{114}$ Despite being built upon a major fault line, Haiti had no building codes. Nearly 300,000 homes were badly damaged or destroyed. The earthquake struck near Port-au-Prince, destroying many of the most important government buildings, hospitals and roads, and laying waste to Haiti's infrastructure. Haiti also endured a cholera outbreak, in October $2010^{115}$ and was hit by two further hurricanes in 2011. Although the cholera outbreak was introduced by UN peacekeepers, its impact was intensified by pre-existing damage to infrastructure, sanitation and health occasioned by the January 2010 calamity which created a 'favourable circumstance' for an epidemic. ${ }^{116}$

Haiti highlights how vulnerability becomes predictable and increasingly likely over time for certain groups. This displaces the notion of disasters producing indiscriminate harm and highlights how certain marginalised groups are disproportionately and differentially vulnerable $\mathrm{e}^{117}$ due to 'pre-existing systems of stratification', with the environment being revealed as a politicized landscape. ${ }^{118}$ Thus, a trajectory of vulnerability emerges which operates in a fashion not unlike that of compound interest. Once vulnerability is concretised into catastrophe, further catastrophe becomes more likely. This phenomenon of intensifying vulnerabilities would have seemed an obvious one for the draft Articles to have investigated.

\section{B.Stratified Vulnerability}

The examples of Chile and Haiti highlight how similar disasters have varying impacts upon different States, but the same is true within disaster-struck populations themselves. For example, in 2006, the UN Human Rights Committee, in its Concluding Observations on the second and third US periodic reports, referenced the events of Hurricane Katrina. ${ }^{19}$ It expressed specific concern that poor people, and in particular African-Americans, were disadvantaged by the rescue and evacuation plans, and endured continuing disadvantage under

\footnotetext{
${ }^{109}$ Roughly 20 per cent of the country's population, https://www.thebalance.com/haiti-earthquake-facts-damageeffects-on-economy-3305660.

${ }^{110}$ https://borgenproject.org/10-facts-haiti-earthquake/ See also E. Sewordor, A.M. Esnard, A. Sapat and L. Schwartz 'Challenges to mobilising resources for disaster recovery and reconstruction: perspectives of the Haitian diaspora' 2019 43(2) Disasters 336, 338

${ }^{111}$ http://www.europeanchoralassociation.org/fileadmin/redaktion/Dateien Europa Cantat/Membership/Human Development_Index_2010.pdf.

112 Borgen Project (n 110).

$113 \mathrm{https}: / /$ www.thebalance.com/haiti-earthquake-facts-damage-effects-on-economy-3305660.

114 'Impact of the 12 January Earthquake' https:/www.dec.org.uk/articles/haiti-earthquake-facts-and-figures.

115 By July 20115,899 had died as a result of the outbreak, and 216,000 were infected, https://www.dec.org.uk/articles/haiti-earthquake-facts-and-figures.

${ }^{116}$ R. Piarroux et al 'Understanding the Cholera Epidemic, Haiti' (2011) 17(7) Emerg Infect Dis. 1161. 'SecretaryGeneral Apologizes for United Nations Role in Haiti Cholera Epidemic, Urges International Funding of New Response to Disease', https://www.un.org/press/en/2016/sgsm18323.doc.htm. A. Sidder 'How Cholera Spread So Quickly Through Haiti' National Geographic 18 August, 2016.

${ }^{117}$ L. Butterbaugh, Why Did Katrina hit Women So Hard? (2005) 35 (9/10) Off Our Backs 17

118 Nix (n 59) 1.

119 Concluding Observations of the Human Rights Committee on the Second and Third U.S. Reports to the Committee (2006) U.N. Doc. CCPR/C/USA/CO/3 (2006). See also J. Rivera, D. S. Miller, 'Continually Neglected: Situating Natural Disasters in the African American Experience', (2007) 37(4) J.of Black Studies, 502.
} 
reconstruction plans. ${ }^{120}$ In acknowledging deep-rooted, systemic disadvantage of AfricanAmericans in the Louisiana area, the UNHRC thus acknowledged and urged the US to review of practices and policies in line with its obligations to protect life and to prohibit (direct and indirect) discrimination. ${ }^{121}$

However, despite all of the foregoing examples, and the clear relevancy of pre-existing hardships to the intensity of a disaster's impact, the ILC Special Rapporteur very early on explicitly rejected any inquiry into a calamity's root cause. Rather than this responding to States' demands (which as noted focussed on averting obligations of external actors to offer/provide disaster aid, clarifying duties of cooperation and restricting disaster-struck States' aid-refusal ${ }^{122}$ ) Valencia-Ospina argued instead that the need for protection arose from the disruption itself, not the originating causal phenomena. ${ }^{123}$ Such an approach casts the notion of root causes as scientific or geographical phenomena, inquiring, for example, into why tectonic plates of the earth moved. Perhaps the Special Rapporteur wished to avoid being drawn into complex scientific debates about a disaster's causation or to avert the Articles' possible, and unwelcome, instrumentalisation in delictual/tortious actions. However, such a construction of root causes is linear and minimal in its time-frame, considering only immediately preceding events. This narrowness continued in draft Article 3's definition of what constituted a disaster: large loss of life, great human suffering and distress, mass displacement, or large-scale material or environmental damage, and serious disruption of the functioning of a society. ${ }^{124}$ Thus, in the draft Articles (as in other instruments such as the 1998 Tampere Convention on the Provision of Telecommunication Resources for Disaster Mitigation and Relief Operations) the issue of causation was confined to what a disaster causes rather than what causes a disaster.

While disasters certainly arise from complex sets of circumstances ${ }^{125}$ (and many States rejected distinctions between natural and man-made disasters ${ }^{126}$ ) exposure to hazards and diminished community resilience is generally what produces catastrophic consequences. Thus, a sensitive re-think of root-causes could allow for a better contextualisation of disaster-risk and remedial measures. This in turn would enjoy greater credibility if deriving from more sophisticated historical and structural analysis. Careful handling would avoid the dangers of superficial discourse or the actual concealing of root causes which Susan Marks has warned against. ${ }^{127}$ Indeed, this deeper approach echoes the Capability/Capabilities approach of

\footnotetext{
${ }^{120}$ For discussion on the engagement of local populations post-disaster see Ali (n 85) 87-95, 265-270. 273-278.

${ }^{121}$ See Arts 6 and 26 of the ICCPR. See also Ali (n 85) 270-272.

${ }^{122}$ See generally O’Donnell \& Allan (n 4), (n 97) and (n 100).

${ }^{123}$ See Valencia-Ospina, Second Report, A/CN.4/615 (n 75) para 49.

${ }^{124}$ Valencia Ospina, Eighth Report, (n 17) para 69, Draft Article 3's Commentary, A/71/10 (n 13) para 5.

125 Draft Art 1 Commentary, A/71/10 (n 13) para 2 and Valencia Ospina, Eighth Report (n 17) para 88. Some causes are accidental, some not, see M.Davis, Late Victorian Holocausts: El Niño famines and the making of the Third World 279 (Verso 2001).

126 'such a distinction could be artificial and difficult to sustain in practice in view of the complex interaction of different causes leading to disasters' Valencia-Ospina, Eighth Report. (n 17) para 47, and draft Art 3 Commentary, A/71/10 (n 13) para 4

127 'If the 'root causes' discourse that has emerged within human rights circles reveals some aspects of the explanation for human rights abuse, ... it can also conceal other aspects. In particular, ... flaws have been illuminated at the level of law, procedure and policy. Yet these flaws have been made to seem like simple misunderstandings or oversights, deficiencies of leadership or accountability, or quirks of local history or culture. The idea that they may themselves be explicable with reference to some wider systemic context has been mostly removed from view. For all the insistence that human rights abuses and the vulnerabilities which expose people to them are man- made disasters, the drift of our analysis is that natural disaster is the model on which the explanatory effort is imaginatively constructed.' S Marks (n 6).
} 
Amartya $\operatorname{Sen}^{128}$ and Martha Nussbaum ${ }^{129}$ respectively which has found favour among climate justice thinkers. This approach resonates with the fact that climate disasters fundamentally destroy and undermine capabilities unless vulnerability and exposure are reduced and resilience building is actively pursued. ${ }^{130}$ The approach appeals because of its sense of procedural justice. Impartial and practical public reasoning could embrace the consequences of decisions taken about populations who are spatially and (given the inter-generational dimensions ${ }^{131}$ ) temporally distant. The approach is especially concerned with capability failures which result from discrimination and marginalisation, and which in turn entrench social injustice and inequality. This article does not focus on the analytical framework of the capabilities approach, but the question that it poses - 'what can this state/community/society do?' - chimes with a rethinking of what 'vulnerability' could be, because it too advocates a stepping away from an average or 'reasonable' standard towards a more nuanced, sensitive analysis of disaster prone/affected communities.

On a plain reading of the 2010 earthquake examples, Haiti's Government appeared to have been less vigilant than that of Chile in regard to its people's safety. It apparently tolerated corruption and is certainly less educationally and technologically developed. However, that analysis emphasises national agency and decision-making. It positions measures like building codes and civilian education as vaccination measures which it would be negligent to overlook. Indeed such measures reflect draft Article 9's calls for States to reduce disaster risks through the conduct of risk assessments, the collection and dissemination of risk and past loss information, and the installation and operation of early warning systems.

According to the ILC standards, Chile's 2010 performance regarding preventive and immediate post-disaster practices appears exemplary. However, Chile and Haiti have very different histories and politics, producing very different vulnerabilities. It is impossible to address and judge their situations fairly without acknowledging that. ${ }^{132}$ While not solely an explanation of its poverty and vulnerability, Haiti's payment of an 'independence debt'/reparations to France of 150 million French Francs (then 10 times Haiti's annual income and in modern terms $\$ 21$ billion dollars) should not be ignored. This required Haiti to borrow money from French and US banks. The loan only concluded in 1947 and, at the very least, deserves attention in assessing Haiti's vulnerability today. ${ }^{133}$ Indeed, the Haitian government issued an official demand to France in 2004 for repayment of the independence debt, the President stressing that this 'grave injustice' hindered Haiti's development. ${ }^{134}$ As Lyster notes, in developing countries, the capacity for disaster response depends on having the financial resources to engage in adaptation and disaster risk reduction activities. ${ }^{135}$ It is a point worth emphasising, however self-evident.

\footnotetext{
${ }^{128}$ A. Sen The Idea of Justice (Penguin 2009).

${ }^{129}$ M.C. Nussbaum, Creating Capabilities (2011: Cambridge MA, Belknap, HUP).

${ }^{130}$ R. Lyster, Climate Justice and Disaster Law, (CUP 2015) xix, 105-107.

${ }^{131}$ See J. Thompson Intergenerational Justice (Routledge 2013)

132 See generally M. Davis (n 125) 279-310 (for an excellent analysis of the production of vulnerability and underdevelopment).

${ }^{133}$ I. Macdonald 'France's debt of dishonour to Haiti' The Guardian 16 August 2010.

$134 \quad$ https://www.telesurtv.net/english/news/France-Clarifies-It-Wont-Repay-Haitis-Independence-Debt-

20150511-0032.html. See also politically-motivated US involvement in Haiti and its relationship to the latter's condition in 2010 which may suggest its own obligation of reparations. B.Quigley 'Why the US Owes Haiti Billions' https://www.huffingtonpost.com/bill-quigley/why-the-us-owes-haiti-bil_b_426260.html.

${ }^{135}$ Lyster (n 131) 106
} 
As a separate point, France's refusal to consider repaying the independence debt, even after the 2010 catastrophe, stood in contrast to the World Bank and some other governments' 'forgiveness' of remaining parts of Haiti's debt ${ }^{136}$ and, indeed, France's own willingness to write-off another loan with a balance of $\$ 77$ million. As well as highlighting some important underlying factors of Haiti's vulnerability (which comprises, but is not solely about, poverty ${ }^{137}$ ) this financial interaction between the two States illustrates the relational nature of vulnerability: one community's strength is produced or preserved at the cost of another community's exposure. ${ }^{138}$ Appreciating intertwined histories may recast understandings regarding the duty of international cooperation currently articulated in draft Article $7^{139}$ and the commentaries to draft Article 9 elaborating on disaster risk reduction obligations.

\section{DEVELOPING AND RE-THINKING DISASTER VULNERABILITY}

In the disaster context, the dominant theoretical schools of thought regarding vulnerability long posited in opposition to each other were the 'physicalist' and 'structural' approaches. However, an analytical shift has appeared in the multi-disciplinary field of disaster studies. Such approaches are potentially rich resources for disaster law given their encounters with familiar struggles in turning away from an isolated (and isolating), episodic ${ }^{140}$ perspective on disasters. Such inquiries have similarly sought to reveal both the unevenness of exposure and the fact that disasters (and disadvantage) are not naturally organic but are instead 'rooted in everyday life'. ${ }^{141}$ As such, they would certainly have enhanced the drafting of relevant legal provisions and the credibility of disaster law.

Physicalism typically stressed physical environment and management perspectives, casting disasters as unavoidable, extreme geophysical events occurring in a nature independent of society. Vulnerability was located as 'a function of mainly biophysical and sometimes technological risk'. This paradigm assumed

that scientific expertise and technological solutions are always the best options for predicting and preventing threats thereby reducing risk and vulnerability. It emphasises the pre-eminence of bureaucratically organised institutions that hire and pay specialised professionals. ${ }^{142}$

Arguably, it potentially but problematically produces an elevated status for (mainly Western) experts, technology and knowledge, promotes a capitalistic worldview, focuses upon new manufactured risks in contemporary societies and encourages a widespread uncritical

\footnotetext{
${ }^{136}$ A fund to which France contributed - http://www.worldbank.org/en/news/press-release/2010/05/28/worldbank-announces-total-cancellation-of-haitis-debt.

137 'Poverty is defined by historical processes that deprive people of access to resources while vulnerability is signified by historical processes that deprive people of the means of coping with hazard without incurring damaging losses that leave them physically weak, economically impoverished, socially dependent, humiliated and psychologically harmed', G.Bankoff 'Rendering the World Unsafe: 'Vulnerability' as Western Discourse' (2001) 25(1) Disasters 19, 25 citing Chambers, 1989, 1.

Vulnerability has since been helpfully categorised into six distinctive types: economic; technological; residual (lack of modernisation); delinquent (corruption, negligence); newly generated and total (general precarity) B. Wisner, D. Alexander (2013) 'Vulnerability' in: K. Penuel, M. Statler and R. Hagen, eds, Encyclopedia of Crisis Management, (Sage 2013) 980-983.

${ }^{138}$ R.Drayton, The Caribbean and the Making of the Modern World.

139 'In the application of the present draft articles, States shall, as appropriate, cooperate among themselves, with the United Nations, with the components of the Red Cross and Red Crescent Movement, and with other assisting actors.'

${ }^{140}$ R .Johnson 'Periods of Peril: Windows of Vulnerability and Other Myths' (1983) 61(4) Foreign Affairs 950.

141 Wisner (n 1).

142 Gibb (n 5) 328 drawing on K.Hewitt 'The idea of calamity in a technocratic age' in K.Hewitt (Ed.) Interpretations of Calamity (Allen and Unwin 1983).
} 
acceptance of orthodox science. ${ }^{143}$ Physicality's sharpest critiques have suggested complicity between the 'conservative attitudes' of dominant national and international actors, and proposed solutions emanating from engineering firms based in the Global North. ${ }^{144}$ Some have even suggested that such solutions create a false sense of security and actually compromise disaster risk reduction. ${ }^{145}$ Nevertheless, despite clear concerns and challenges, the physicalist approach endures and arguably dominates the approach of governments, the UN and its agencies, and multilateral funding institutions.

The 2009 definition of vulnerability used by the UN Office for Disaster Risk Reduction (UNISDR) referred to 'The characteristics and circumstances of a community, system or asset that make it susceptible to the damaging effects of a hazard.' The definition's accompanying comment clarified that vulnerability comprised many aspects (including some familiar examples ${ }^{146}$ ) but importantly it also stated that "Vulnerability varies significantly within a community and over time.' 147 This appeared as a sensitive and nuanced characterisation which allowed for deeper inquiry into risk exposure. However, a desire to develop a set of indicators to measure global progress in the implementation of the aforementioned Sendai Framework resulted in the UN General Assembly establishing an open-ended intergovernmental expert working group. ${ }^{148}$ Its report was duly adopted by the UNGA on February $2^{\text {nd }}, 2017 .{ }^{149}$ The revised definition of vulnerability clearly reflects the Sendai definition ${ }^{150}$ and now refers to

...conditions determined by physical, social, economic and environmental factors or processes which increase the susceptibility of an individual, a community, assets or systems to the impacts of hazards.

These influential definitions impact upon governmental decision-making. The leading critical geographer Ben Wisner is highly critical of the new UNISDR definition, which he considers a retrograde step given its capacity to both privilege and exclude certain domains of human life. ${ }^{151}$ In particular, he takes issue with the terminology of 'community' and the general brevity of the new definition.

The reader is left assuming that this socio-spatial unit contains homogeneous people all vulnerable at the same time to the same degree. In 2009 this ambiguity was partly eliminated by the phrase, 'Vulnerability varies considerably within a community over time'. ... it would have been more accurate to say, 'within a community and over time', flagging the

\footnotetext{
${ }^{143}$ Gibb (n 5) 328 drawing on, among others, A.Giddens 'Risk and Responsibility' (1999) 62(1) MLR 1 and T.Forsyth Critical Political Ecology (Routledge 2003).

${ }^{144}$ Gibb (n 5) 330 drawing on M. Pelling 'Natural Disasters?' in N.Castree, B.Braun (Eds.), Social Nature (Blackwell 2001).

${ }^{145}$ See G.Bankoff, 'The tale of the Three Little Pigs: Taking Another Look at Vulnerability in the Light of the Indian Ocean Tsunami and Hurricane Katrina' http://understandingkatrina.ssrc.org/Bankoff/ and Gibb (n 5) 330, drawing on N.Smith 'There's No Such Thing as a Natural Disaster, Understanding Katrina: perspectives from the social sciences' (Social Science Research Council:2006).

146 Poorly designed and constructed buildings, inadequate protection of assets, lack of public information and awareness, limited official recognition of risks and preparedness measures, and disregard for wise environmental management.

$147 \quad$ UNISDR 2009 Terminology on $\quad$ Disaster $\quad$ Risk https://www.unisdr.org/files/7817_UNISDRTerminologyEnglish.pdf.

${ }^{148}$ UN General Assembly Resolution 69/284.

${ }^{149}$ Report of the open-ended intergovernmental expert working group on indicators and terminology relating to disaster risk reduction (2016) A/71/644.

150 'The conditions determined by physical, economic, social and environmental factors, which increase the susceptibility of a community to the impacts of a hazard.' This repeated the 2005-2015 Hyogo Framework for Action definition (n 25).

${ }^{151}$ Wisner (n 1).
} 
reality that there are winners and losers in every situation and considerable differentiation among people in primary socio-spatial units.

As noted already, while physicalism arguably endures at the institutional level, structuralist approaches have dominated recent scholarship with a 'bumper crop' of historical research demolishing 'orientalist stereotypes of immutable poverty and overpopulation as the natural preconditions of the major nineteenth-century famines. ${ }^{152}$ The structural approach sought a more complex, deeper-rooted and people-centred perspective on disasters via the application of social scientific analysis. Without rejecting a scientific dimension, it took into account structural and historical factors which create societal inequalities and unequal distributions of vulnerability. Wisner is particularly influential in this discourse, ${ }^{153}$ alongside the geomorphologist Kenneth Hewitt, whose book Interpretations of Calamity ${ }^{154}$ stressed that it is 'the everyday social interactions and structures embedded in broader historical circumstances' and a natural hazard's particularities, that ultimately determine its nature, causes and consequences. ${ }^{155}$ This influenced the theorisation of new models ${ }^{156}$ focussing upon the processes of marginalisation and exclusion which produced vulnerability and possible disaster. Marginality might varyingly be geographical, political or social but it always explains the uneven apportionment of risk and stresses that vulnerability results from social systems. However, to avoid a rather one-dimensional focus on marginality, a multidimensional portrayal of disasters reflecting the 'totality of relationships' could be achieved by analysing the interrelationship between political, economic and social factors and environmental issues and changes, so-called 'political ecology' ${ }^{157}$ to be discussed shortly.

Beyond his terminological anxieties regarding the UNISDR definition of vulnerability Wisner criticises the 'striking' absence of references to politics, ${ }^{158}$ the role of power relations ${ }^{159}$ or institutional failures. ${ }^{160}$. For Wisner, models of vulnerability are actually 'expanded definitions (sometimes taxonomies) that suggest, to various degrees of detail, the biophysical

\footnotetext{
${ }^{152}$ M. Davis 'The Political Ecology of Famine' in R.Peet (ed.) Liberation Ecologies (2 ${ }^{\text {nd }}$ edn. Routledge 2004$) 44$ at 53 .

${ }^{153}$ B. Wisner et al, At Risk: Natural hazards, people's vulnerability and disasters. (2 ${ }^{\text {nd }}$ edn. Routledge 2004)

154 (Allen and Unwin 1983).

${ }^{155}$ Gibb (n 5) 327 see also K. O’Brien, S. Eriksen, L. P. Nygaard, A. Schjolden 'Why different interpretations of vulnerability matter in climate change discourses' Climate Policy, 7(1) (2007), 73-88. See also Wisner et al (n 154).

${ }^{156}$ See for example the 'spaces of vulnerability' model, Gibb (n 5) 329, citing M. Watts and H. Bohle 'Hunger, famine and the space of vulnerability' (1993) 30(2) Geo Journal 117. See also Wisner et al (n 154) and the pressure and release model.

${ }^{157}$ P. Robbins Political Ecology (Chichester, Malden: Wiley, 2011) $2^{\text {nd }}$ ed., for illustrations see also K.A. Gould, M.M.G. Jacob, A.C. Remes, 'Beyond "natural disasters are not natural": the work of state and nature after the 2010 earthquake in Chile' (2016) 23 J. of Polit.Ecol. 93, P. Walker 'On 'Reconsidering Regional Political Ecologies' 13 years on', Journal of Political Ecology (2016) 23 J. of Polit.Ecol. 123, A. Koensler and C. Papa 'Introduction: beyond anthropocentrism, changing practices and the politics of 'nature' (2013) $20 \mathrm{~J}$. of Polit.Ecol. 286. For critical perspectives see A. Vayda and B. Walters 'Against political ecology,' (1999) 27 Human Ecology 167, A. Vayda and B. Walters 'Event ecology, causal historical analysis, and human-environment research" (2009) 99(3) Annals of the Association of American Geographers 534. For some thoughts on resolving theoretical conflicts see R. Penna-Firme 'Political and event ecology: critiques and opportunities for collaboration' (2013) 20 J. of Polit.Ecol. 119.

${ }^{158}$ A. Mascarenhas \& B. Wisner, 'Politics: Power and Disaster', in B. Wisner, J. C.Gaillard and I. Kelman, (eds,) The Routledge Handbook of Hazards and Disaster Risk Reduction, 48 (Routledge 2012).

${ }^{159}$ See Wisner (n 1) and his citation of D. Alexander 'Vulnerability' in: K. Penuel, M. Statler and R. Hagen, (eds), Encyclopedia of Crisis Management, (2013) 980.

${ }^{160}$ See Wisner ibid and his citation of M. Anderson \& P. Woodrow, Rising from the Ashes: Development strategies in times of disaster, (Lynne Rienner (1998 [1989])).
} 
and social processes that combine to produce susceptibility to loss and harm, and obstacles to recovery." ${ }^{161}$ Unsurprisingly, he is drawn to work which suggests that vulnerability can be conceptualized at a series of increased degrees of complexity and scale ${ }^{162}$ and to those who define vulnerability as encompassing 'long-term factors which affect the ability of a community to respond to events or which make it susceptible to calamities'. ${ }^{163}$ In his own landmark work At Risk, Wisner posits what has become a key definition in the disaster discourse:

By vulnerability we mean the characteristics of a person or group and their situation that influence their capacity to anticipate, cope with, resist and recover from the impact of a natural hazard (an extreme natural event or process). ${ }^{164}$

This more socially constructed understanding of vulnerability makes space for investigating and explaining why someone or something is vulnerable. It may be possible to respond via the 'pressure and release' model, which suggests pressure is released through changes in institutions, structures of domination and improved access to resources. ${ }^{165}$ It will be suggested below that it is not beyond a legal definition/ interpretation of vulnerability to capture these dynamics.

New developments do not necessarily imply revolution and there can be adaptation, rather than abandonment, of existing legal regimes. For example, innovative legal reconceptualisations of 'community interests' have not challenged traditional institutions and consequently, as such, these new concepts have actually been accepted by States. ${ }^{166}$ The same creativity could be applied to the hallmark duty of international co-operation in draft Article 7 which might more clearly address relational responsibilities (both contemporary and historical). Similarly, a more innovative design of draft Article 9 which avoids heaping responsibilities on disaster-prone States as if they are identical to, and possess the same capacities as, each other, would represent some steps forward in the deeper and more meaningful conceptualisation of vulnerability. It might also potentially produce more effective disaster-reduction and coping strategies. An example of more dynamic legal perspectives is offered in the 2018 General Recommendation No. 37 issued by the Committee on the Elimination of All Forms of Discrimination against Women. This instrument recognises both the constructed nature of vulnerability and the possibilities of extending agency more meaningfully to so-called vulnerable groups when it states

6.As the higher vulnerability and exposure of women and girls to disaster risk and climate change are economically, socially and culturally constructed, they can be reduced. The level of vulnerability may vary according to the type of disaster and the geographical and sociocultural contexts.

7.The categorization of women and girls as passive "vulnerable groups" in need of protection from the impacts of disasters is a negative gender stereotype that fails to recognize the important contributions of women in the areas of disaster risk reduction, postdisaster management and climate change mitigation and adaptation strategies. Welldesigned disaster risk reduction and climate change initiatives that provide for the full and

\footnotetext{
${ }^{161}$ Wisner ibid.

162 J. Birkman, 'Measuring vulnerability to promote disaster-resilient societies: conceptual framework and definitions' in: J. Birkmann, ed, Measuring vulnerability to natural hazards, 9 (United Nations University Press 2006).

163 Anderson \& Woodrow (n 161).

${ }_{164}$ Wisner et al (n 154) 11.

${ }^{165}$ Wisner et al ibid.

${ }^{166}$ S. Villalpando, 'The Legal Dimension of the International Community: How community interests are protected in international law' (2010) 21 E.J.I.L. 387, 409-410.
} 
effective participation of women can advance substantive gender equality and the empowerment of women, while ensuring that sustainable development, disaster risk reduction and climate change objectives are achieved.

It seems that shifts in conceptualisations of disaster-prone peoples are in the ether. Wider disaster law should seize this initiative.

\section{PROBLEMATISING VULNERABILITY}

Vulnerability and structural analyses exert a powerful draw upon those configuring disasters in a deeper, more complex way, and who understand disasters as representing the violence of the everyday for some communities. ${ }^{167}$ Understandings of inter-related histories and the role of economics (which are inherent to political ecology) compare well against physicality's myopic one-dimensionalism. However, some have urged caution as regards the structural approach of vulnerability, reminding us that disasters are not entirely socially-constructed and there should always be an appreciation of the inter-relationship of social and geophysical causes. ${ }^{168}$ Bearing this in mind, the suggestion of a 'nested and tele-connected approach', (discussed in the article's last substantive section) is compelling.

As a pejorative term, 'vulnerability' is as susceptible to ideological assault and elite appropriation as any other. ${ }^{169} \mathrm{~A}$ secondary, and probably more fatal, critique of the structural approach is the charge that it represents simply another conceptual framing which simplistically and problematically characterises certain regions of the world as 'dangerous', with the danger now being one of hazard rather than disease or poverty. ${ }^{170}$ This has implied troubling territories, societies or people in need of assistance (often externally provided). ${ }^{171}$ Such operationalisation has been accused of more, or better, serving external interests rather than those ascribed the status of vulnerable.

The critical historian Gregory Bankoff who identifies as 'a non-western historian who adopts an inter-disciplinary approach that combines the social with the natural sciences, theoretical insights with historical perspectives', ${ }^{172}$ has long critiqued notions of vulnerability in disaster discourse. ${ }^{173} \mathrm{He}$ charts the problematic discursive trajectory regarding these 'dangerous unfamiliar parts of the world' as beginning with 'Tropicality' (which rationalised colonialism and the Western medical 'cure'), continuing through to 'Development' (which sustained external aid) and currently culminating in 'Vulnerability' (which justifies the intervention of 'relief'). Such imaginative geography

... establishes defenceless spaces with its pattern of frailties and absent protection ... and spaces of vulnerability determined by lack of entitlement, enfranchisement and empowerment ... these zones are often also denominated regions of misrule where a

${ }^{167}$ K. C. Lauta Disaster Law (Routledge, 2015)

${ }^{168}$ H. Brookfield, 'Environmental damage: distinguishing human from geophysical causes'(1999) 1(1) Global Environmental Change Part B: Environmental Hazards, 3. See also S. Fuchs 'Susceptibility versus resilience to mountain hazards in Austria - paradigms of vulnerability revisited' (2009) 9 Nat. Hazards Earth Syst. Sci., 337.

169 Gibb (n 5) 331-332, referencing Forsyth (n 144).

${ }^{170}$ Bankoff, (n 137) discussed extensively below

${ }^{171}$ A Anghie Imperialism, sovereignty and the making of international law (CUP 2005), A. Anghie, B. Chimni, K Mickelson \& O.C. Okafor (eds) The Third World and International Order (Nijhoff 2003), B. Fassbender, A. Peters, The Oxford Handbook of the History of International Law (Oxford OUP, 2014).

$172 \mathrm{http}: / /$ www2.hull.ac.uk/Faculties/staff-profiles/Professor-Greg-Bankoff.aspx.

173 Bankoff (n 137), G. Bankoff, G. Frerks and T.Hilhorst (eds.), Mapping Vulnerability: Disasters, Development and People, (Abingdon, New York: Earthscan, 2004), G. Bankoff, 'No Such Things as "Natural Disasters": Why We Had to Invent Them', Harvard International Review, 24 August 2010, http://hir.harvard.edu/no-such-thingas-natural-disasters. G. Bankoff, 'Comparing Vulnerabilities: Toward Charting an Historical Trajectory of Disasters’, (2007) 32(3) Historical Social Research 103. 
population's vulnerability [is] made worse by the operation of despotic or illegitimate governments. ${ }^{174}$

For Bankoff, modern renditions of the 'danger tale' and characterisations of 'cure' are dominated by notions involving 'the transfer and application of Western expertise, ... in the form of meteorological and seismic prediction, preventive and preparedness systems, and building and safety codes'. Thus, despite the apparent lexical and conceptual developments of 'vulnerability', if environment persists as the 'decisive quality in determining the condition of danger posed by this "other" world', then the historical and cultural geography of risk prevails and simultaneously terrifies the West. It justifies its intervention and leaves its discourse unchanged, thereby facilitating the construction of certain societies and peoples 'as weak, passive and pathetic'. ${ }^{175}$ Further, despite vulnerability's good intent, and even with its less environmentally deterministic measure of gauging population risk-exposure, vulnerability cannot escape its detached and compartmentalising perspective. It still allows (in both social and natural science contexts)

Western governments to talk and act in international fora as if disaster, poverty, disease and the environment are entirely unrelated issues that need not be tackled concurrently but dealt with separately, according to a timetable largely determined by themselves. ${ }^{176}$

Even at its worst, physicality was arguably an honest effort at framing of disasters, whereas structural vulnerability has been charged as an insidious method of passing responsibility to the less powerful, while cheaply managing and controlling the capacities of the 'previously-marginal-newly-empowered citizens' ${ }^{177}$ This disingenuous foregrounding of agency, in combination with solutions which rely on the (false) nature/culture dichotomy, ${ }^{178}$ sidesteps perspectives which interrogate links between processes and outcomes ${ }^{179}$. The relational aspect of vulnerability's theorisation is highlighted by Western theory's inability to offer an uncompromising and radical self-critique. The world is thus changed in ways that maintain the interests of current beneficiaries. ${ }^{180}$ As with tropicality and development, for Bankoff, since vulnerability emerges from knowledge systems 'formed with a dominant Western liberal consciousness', it inevitably reflects those values and principles. ${ }^{181}$ Given all of the foregoing, any potential for the 'vulnerability lens' to appeal in the disaster context seems demolished. But it is not the last word.

\section{THE ENDURING VALUE OF VULNERABILITY}

Even Bankoff acknowledges that the conceptualisation of vulnerability is not valueless and has represented certain theoretical and methodological advances. Notably, it has allowed for the socio-economic, political and environmental contextualisation of disasters, and has provided a helpful guide for formulating hazard-preparedness and relief-provision approaches and policies. What is required is a re-think and self-conscious application of the concept employing notions of relational vulnerability and political ecology.

\footnotetext{
${ }^{174}$ K. Hewitt, Regions of Revolt. A Geographical Introduction to Disasters (Longman 1997) 164-165, Watts \& Bohle, (n 157) 121 cited with approval by Bankoff (n 137) 26.

${ }^{175}$ Bankoff, ibid, 27-29, citing with approval the work of Hewitt, 167.

176 Bankoff, ibid, 28.

${ }^{177}$ Gibb (n 5) 332 referencing A. Gupta and A. Sharma 'Globalization and Postcolonial States' (2006) 47(2) Curr. Anthropol. 277.

${ }^{178}$ See Koensler and Papa (n 158) and B. Latour's challenge in We Have Never Been Modern (Cambridge, Mass., Harvard University Press:1993).

${ }^{179}$ Gibb (n 5) 332, drawing on the work of T. Mitchell Rule of experts: Egypt, Techno-politics , Modernity (U.of Cal. Press:2002).

${ }^{180}$ Bankoff (n 137) 29 citing Guha, 1997:11 and 6-7.

${ }^{181}$ Bankoff, ibid, 29.
} 
In its essence, 'vulnerability' denies the dismissal of root causes. Despite their dramatic manifestation, disasters lie along a 'continuum whose origins lie buried in the past and whose outcomes extend into the future'. ${ }^{182}$ Failure to recognise this, and the adoption of onedimensional, formulaic constructions of disaster-processes, will inevitably compromise societal capacity to withstand a disaster and to recover. Disasters principally emerge from interactions between humans and the environment. As totalising 'moments of catharis', they often reveal societal disrespect for, and ignorance about, the environment and the lack of 'mutuality' in the relationship. ${ }^{183}$ This disrespect is perhaps more a feature of modernity than of indigenous environmental stewardship practices. Notably neither the words 'steward' or 'stewardship' appear in the ILC draft Articles or their commentaries. Given legislative initiatives and the increasing wealth of scholarship embracing such notions, ${ }^{184}$ this seems an oversight especially since such inquiries would yield an appreciation of the divergence in cultural perspectives regarding risk. As Ulrich Beck noted, the concept of risk is directly bound to the concept of reflexive modernization. ${ }^{185}$ In Western control-oriented thinking, hazards and disasters are injurious aberrations to be prevented, tamed, corrected. As Stephens notes in reflecting upon the Hyogo and Sendai frameworks

These measures do not truly face up to the reality of the Anthropocene, based as they are on an assumption that risk can be adequately mapped and understood and avoided. In this vision disaster risk is a matter of technical and technological challenge rather than an allencompassing threat. ${ }^{186}$

The irony is that modern societies are increasingly preoccupied with debating, preventing and managing self-produced perils as seen in the cyclical deployment of risk-assessment exercises. This is not necessarily malignly intentioned but it is a situated perspective rooted in technocracy and remedial measures. There is apparently less acceptance of notions of the everpresence or embeddedness of hazards, threats and disasters, as if such acceptance would imply the abandonment of entire communities to terrible fates.

An alternative perspective might reflect upon so-called threat 'normalisation' not as resignation or defeat, but rather in terms of its revelatory capacity regarding in-built coping mechanisms and cultural adaptability. ${ }^{187}$ Perhaps what risk/hazards/disasters discourse demands is a proper cosmopolitan turn which is entirely rooted in mutual respect and

\footnotetext{
182 Bankoff, ibid, 30.

${ }^{183}$ Bankoff, ibid, 30 citing Hoffman and Oliver-Smith (n 19) 6, 20.

${ }^{184}$ D. Antolini 'Marine Reserves in Hawai'i: A New Call for Community Stewardship' (2004) 19(SUM) Nat. Resources \& Env't 36, D.S. Wilgus 'The Nature Of Nuisance: Judicial Environmental Ethics and Landowner Stewardship in the Age of Ecology' (2001) 33 McGeorge L. Rev. 99, E.R. Rampersad 'Indigenous Adaptation to Climate Change: Preserving Sustainable Relationships Through an Environmental Stewardship Claim \& Trust Fund Remedy' (2009) 21 Geo. Int'l Envtl. L. Rev. 591, D. Shelton 'Dominion And Stewardship' (2016) 109 AJIL Unbound 132, T. Simpson-Wood 'Changes in Latitudes Call For Changes in Attitudes: Towards Recognition of a Global Imperative For Stewardship, Not Exploitation, in the Arctic' (2014) 37 Seattle U.L.Rev. 1239, .R. Gourley 'Towards Ethical Stewardship: Balancing Natural and Historic Cultural Resources in National Parks' (2017) 35 Va. Envtl. L.J. 522, 'Materials On Community Stewardship Entities' (2008) SN055 ALI-ABA 451, 'Heritable Knowledge Framework and the Development of Communal Innovation Trusts: An Ethical Framework for Development, Stewardship and Trade' (2009) 5 (1) IBA Convergence 106, T. Henriksen 'The Arctic Ocean, Environmental Stewardship, and the Law of the Sea' (2016) 6 UC Irvine L. Rev. 61.

${ }^{185}$ U. Beck Risk Society: Towards a New Modernity (Sage 1992).

${ }^{186}$ T. Stephens 'Disasters, international environmental law and the Anthropocene' in Breau and Samuel (n 4) 153, 75.

187 B.R. Cook 'Disaster Management Culture in Bangladesh: the enrolment of local knowledge by decision makers' in F. Krüger, G. Bankoff, T. Cannon, B. Orlowski, E. Lisa, F. Schipper (eds.) Cultures and Disasters: Understanding Cultural Framings in Disaster Risk Reduction (Routledge 2015).
} 
international cooperation. This turning away from terror or pity towards respect could signal a re-imagining of resilience and a proper willingness to engage with indigenous environmental management practices long swept away in the eras of tropicality and developmentalism. ${ }^{188}$

... perhaps too, people's behaviours and activities that may appear maladaptive and obscure to Western social scientists need to be reassessed in the context of the decision-making frameworks within which individuals operate and have come to terms with extreme situations in such an environment. Perhaps the whole notion of threat is so interwoven into the pattern of historical development and daily life that many aspects of culture perceived as distinctive have their origins, at least, partly in the need for collective action in the face of common dangers. ${ }^{189}$

State engagement with such practices could chime with responsibilities to protect populations and prevent disasters. ${ }^{190}$ Indeed UNESCO has established a widely available register of best practices on indigenous knowledge which includes examples and cases illustrating the use of this knowledge to develop cost-effective and sustainable survival strategies for poverty alleviation and income generation. These practices include indigenous land-use systems to encourage labour-sharing arrangements among farmers, using local knowledge to increase the fuel-efficiency of local stoves instead of replacing them, and using indigenous institutions in structural ways. Locally-based, traditional approaches to forecasting seasons and fitting cropping to changing seasonal variabilities are rich resources. ${ }^{191}$ For example, preservation of traditional water harvesting methods in Sri Lanka include the traditional so called 'bethma' practices which combine reservoirs with temporary land redistribution and occasional field rotation. ${ }^{192}$ In Niger, traditional planting pits are re-purposed as water collecting reservoirs, thereby imitating part of a soil improvement technology traditionally used in other parts of the country and in Burkina Faso. ${ }^{193}$ Carefully documented case histories can focus on the ways that such knowledge has been adapted, applied, and disseminated and thereby provide excellent guidelines for policy making and planning new projects.

Writing recently, the critical geographer Christine Gibb also recognises the shortcomings in the structural vulnerability model as being ideological, overemphasising of human agency, resting upon a problematic reproduction of the nature-culture dualism and ultimately reproducing a damaging discourse of Western hegemony. For example, sometimes even when indigenous knowledge is invoked in academic debates in science, or humanities and social science, local expertise is too often being evaluated as data or evidence, rather than as knowledge or theory in its own right which might contribute different perspectives. ${ }^{194}$ Gibb also recognises the tendency in disaster discourse towards treating symptoms rather than causes, and the resistance to addressing vulnerability's deep-rooted nature via serious political change. While the rhetoric of structural vulnerability was regularly deployed at major international summits in the 1990s and 2000s,

\footnotetext{
${ }^{188}$ Bankoff (n 137) 29-31.

189 Bankoff, ibid.

${ }^{190}$ S.C. Breau, 'Responses by States' in Breau and Samuel (n 4) 69.

${ }^{191}$ C.J. Stigter, Zheng Dawei, L.O.Z. Onyewotu and Mei Xurong 'Using Traditional Methods and Indigenous Technologies for Coping with Climate Variability (2005) 70 Climatic Change 255, 264.

192 MOST/CIRAN: 'The bethma practice: promoting the temporary redistribution of lands during drought periods', Sri Lanka, BP.21, Best Practices on Indigenous Knowledge Database, Retrieved from, cited in Stitger et al, ibid.

${ }^{193}$ MOST/CIRAN: 'Improving tassa planting pits: Using indigenous soil and water conservation techniques to rehabilitate degraded plateaus in the Tahoua region of Niger', NIGER, BP.10, Best Practices on Indigenous Knowledge Database, cited in Stitger et al, ibid.

${ }^{194}$ J. Cruikshank 'Glaciers and Climate Change: Perspectives from Oral Tradition' (2001) 54(4) Arctic 377.
} 
$\ldots$ in the final version of summit declarations and documentation normalised beliefs prevailed with the erasure of any traces of the structural perspective and the reinstatement of its physicalist predecessor. ${ }^{195}$

This feels extremely prescient in the context of the ILC draft Articles where much is made of the desire to stand in solidarity with disaster-affected or vulnerable populations, yet the draft Articles, despite some openings, ultimately follow a very conservative path. They ask very little of non-disaster-prone States, beyond broad obligations to internationally co-operate. They also show little understanding of the possible reasons for States' ostensible negligence regarding disaster prevention and mitigation planning, despite such shortcomings perhaps at least in part deriving from the actions of other States or indeed the initiatives of major international institutions. ${ }^{196}$ Such objectification of disaster-prone States is notable in the increased drift towards interventionism (restricting the right to refuse aid in draft Article 13) which challenges traditional State sovereignty. This, however, is coupled with the resistance towards any duty to offer assistance (draft Article 12) which preserves and privileges the sovereignty of external actors including external States. This dual but contradictory approach seems to highlight the stereotyping of disaster-prone populations as problems to be managed, yet it countenances absolutely no responsibility on the part of external actors for historically and continually creating the political, economic and social conditions which have produced that vulnerability. It is this relational version of vulnerability which begs to be addressed in contemporary disaster law. As Christine Gibb notes, when applied to a political ecology approach that both studies the symptoms of vulnerability and tackles root causes,

relational vulnerability offers new possibilities for minimising some of the non-fatal and fatal flaws of the structural vulnerability paradigm. Although an emphasis on the dynamic and relational character of vulnerability does not present easy or comfortable solutions, by situating disasters as a question of power, it offers scholars, practitioners and policy-makers a springboard for just and committed work. ${ }^{197}$

Vulnerability's residual value is revealed by both its relational aspects and a 'nested and teleconnected' approach '...whereby nestedness reflects linkages to local history, social relations and place, and [teleconnectedness] emphasises the networking of local systems, people and places, and their social and economic implications' ${ }^{198}$ By thinking in terms of an enabled environment it may potentially even produce the best version of an enabling environment for disaster risk reduction ${ }^{199}$

A revamped configuration of structural vulnerability is not a theoretical panacea in the disaster context. However, with some self-reflectiveness, the concept retains considerable promise. It creates scope for taking a long view of hazards and disasters. In its essence, it recognises notions of community marginalisation and uneven risk. Such sensitivity lends it agility and contextual awareness which are absent from the taxonomies of vulnerability contouring and dominating contemporary international human rights law. 'Vulnerability' can provide platforms for revisiting and revitalising traditional indigenous coping practices which were intentionally obscured in the colonial project. This article's argument is not a pastoralist fantasy that argues for technology's total rejection. Science can and should continue to play a

\footnotetext{
195 Gibb (n 5) 332.

${ }^{196}$ See the report of the UN Special Rapporteur on extreme poverty and human rights regarding the World Bank and Human Rights https://srpovertyorg.files.wordpress.com/2018/08/world-bank-report-2015.pdf, See also Charlesworth (n 28) 390.

197 Gibb (n 5) 333.

198 Ibid 330-331, drawing on the work of W. N. Adger, H. Eakin \& A. Winkels 'Nested and teleconnected vulnerabilities to environmental change' (2009) 7(3) Frontiers in Ecology and the Environment 150.

${ }^{199}$ A. La Vaccara, ‘An Enabling Environment for Disaster Risk Reduction' in Guttry et al (n 46) 199.
} 
major role in increasing understanding and choosing between options for disaster risk reduction and disaster response. However, equally, differences in environmental concepts and interests between local populations and technocrats should also be explicitly recognised. ${ }^{200}$ In addition, investigating conceptualisations of vulnerability in the disaster field provides opportunities for developing subsequent theorisations of vulnerability more broadly, particularly regarding relational vulnerability. ${ }^{201}$ In this way, it facilitates a more sophisticated understanding of international responsibility beyond its simple attribution to disaster-prone communities alone.

\section{CONCLUSION}

As the opening quotation from Ben Wisner notes, words matter and particular textualisations produce particular outcomes. Despite their potential, the ILC draft Articles ultimately shy away from an ambitious understanding of disaster-vulnerable communities. We are instead gently nudged towards uncritical adoption of the traditional scientific and administrative models of remedying vulnerability. Without engaging in fruitless debates regarding 'authentic' vulnerability, it is worth pondering to what extent pre-ordained cures tailor a malady's construction. It is submitted that although the ILC draft Articles ostensibly addressed 'vulnerability' in fact, this was documented in a way that facilitated and maintained a particular industrial and bureaucratic model excluding all other perspectives. From the perspective of the critical school in international law, the opportunity to revitalise certain key notions of interdependence and community in general, and in disaster law in particular, was missed.

International law is often compelled by public goods and community interests, how they affects inter-State relations and 'the special vulnerability of the public good'. Indeed Villalpando notes how scientific discoveries revealing the irreversible deterioration of natural resources have triggered efforts to preserve the world environment now and for the future. ${ }^{202}$ However, awareness of the need to protect a public good often needs 'a great blaze' to appear, often in the form of disaster. The 2004 Indian Ocean tsunami renewed interest in the protection of disaster-stricken persons ${ }^{203}$ which was then bolstered by the debates regarding the potential applicability of the Responsibility to Protect doctrine in the context of the 2008 Cyclone Nargis in Myanmar. In his discussion of the reactive nature of the discipline, Villalpando interestingly suggests that sometimes key actors in international law can be reacting not just to world events, but also to the unattractive consequences of their own decisions. For example, it might be that the ICJ's development of erga omnes obligations in 1970 in Barcelona Traction, was its way of atoning for the rejection of claims in the 1966 South West Africa cases. ${ }^{204}$

This notion of atonement is an interesting one in the context of the ILC project on disasters. The refusal to recognise or develop a general, external duty to offer assistance to disaster-stricken populations (despite there being as much, if not more basis for this than the duty not to arbitrarily refuse aid) is extremely disappointing. It is a supreme irony that while referencing the interests and needs of the most vulnerable, the ILC has managed to exclude from actually having certain claims to assistance from the international community, the most vulnerable populations. However, it is possible that by re-developing notions of vulnerability,

\footnotetext{
${ }^{200}$ S. Cartier van Dissel, and J. de Graaff, 'Differences between farmers and scientists in the perception of soil erosion: A South African case study’, 1998 6(3) Indigenous Knowledge and Dev. Monitor 4 cited approvingly in Stitger et al (n 192) 266.

${ }^{201}$ Gibb (n 5) referencing M. Taylor 'Climate Change, Relational Vulnerability and Human Security: rethinking sustainable adaptation in agrarian environments' 2013 5(4) Clim. Dev. 318.

202 Villalpando (n 166) 396-397, drawing on Gabcikovo-Nagymaros Project (Hungary/Slovakia), [1997] ICJ Rep.

7 , at 78 , para 140 .

${ }^{203}$ ILC Report Fifty-eighth Session A/61/10 (n 14) para 257 and Annex C paras 3-4.

${ }^{204}$ Villalpando (n 166) 400-401.
} 
there can be atonement for the draft Articles' shortcomings and for some rethinking before any treaty is finalised. Such re-thinking might also afford further recognition and some (tiny) atonement for the after-effects of colonialism, displaying appreciation of its ongoing relational dimensions and consequences. In the particular context of the ILC Draft Articles, such reconceptualising could not disregard the clear submissions from states, IGOs and NGOs as expressed in the consultation process. However, the suggestions offered, regarding draft Articles 7 and 9 in particular, suggest that openings exist for rethinking the textual approach of the law in this area.

Disasters have often been viewed as bitter harvests of past malign or negligent decisions. At the outset of this article, it was noted that globalisation's advent and increased notions of inter-dependence have intensified notions of mutual vulnerability. ${ }^{205}$ This may explain keen interest from the Global North in disasters. However, such an account could be charged as simply representing a self-interested version of the relational concept and associated anxieties regarding risk contagion, rather than an enlightened understanding of how a particular constituency is implicated in producing a catastrophe. Indeed it is poignant that the outcome document of the 2012 United Nations Conference on Sustainable Development, was entitled 'The future we want'. If history and colonialism highlight the perils of reaping what you sow, perhaps now is the time to focus on further seeding the soil of legal contemplation.

${ }^{205}$ J. Nef, 'Human Security, Mutual Vulnerability, and Sustainable Development: A Critical View', (2006) 7 Whitehead J.Dipl. \& Int'l Rel. 55. 